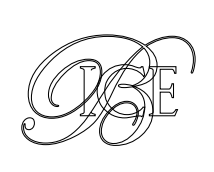

\author{
Subdirección General de Estudios y Evaluación de Instrumentos \\ de Politica Comercial*
}

\title{
LAS CARACTERÍSTICAS DE LA EMPRESA EXPORTADORA ESPAÑOLA (2017)
}

El objetivo de este artículo es caracterizar a la empresa exportadora española de mercancías, para poder comprender mejor la dinámica exportadora y disponer de una útil referencia, para el diseño e instrumentación tanto de la política comercial orientada a las empresas como de sus estratégicas comerciales. Este análisis descriptivo, principalmente de corte transversal para el año 2017, se sustentará sobre las estadísticas de comercio exterior por características de la empresa publicadas por el Departamento de Aduanas e Impuestos Especiales de la Agencia Tributaria y por Eurostat. Se analizará la relevancia que las distintas variables que caracterizan a la empresa tienen en la probabilidad de que las empresas exporten, en el valor de sus exportaciones y en su regularidad. Entre las variables que se examinarán se encuentran el tamaño de la empresa, la actividad principal, el control de la propiedad o si la empresa también está importando.

Palabras clave: España, comercio exterior, exportación, Aduanas, Eurostat, pyme.

Clasificación JEL: F14, F23.

\section{Introducción}

El objetivo de este trabajo es analizar las características de las empresas españolas exportadoras en el año 2017 y compararlas con las de sus homólogas comunitarias. Este análisis permitirá examinar la relevancia que determinadas variables tienen sobre la probabilidad de que una empresa exporte, sobre el valor de sus exportaciones y sobre la regularidad de las mismas.

\footnotetext{
* Ministerio de Industria, Comercio y Turismo. Versión de diciembre de 2019.

DOI: https:/doi.org/10.32796/bice.2019.3118.6941
}

Para realizar el análisis se utilizarán las estadísticas de comercio exterior de bienes por características de la empresa, que publican tanto el Departamento de Aduanas e Impuestos Especiales de la Agencia Tributaria (en adelante, Aduanas) para España como Eurostat para los Estados miembros de la UE. Estos datos son complementarios, y los de Eurostat permitirán, además, realizar una comparativa internacional. El análisis se centra en las características de las empresas exportadoras, pero el lector interesado podría obtener de estas dos fuentes datos análogos correspondientes a las empresas importadoras.

Estas fuentes complementan los análisis de flujos, composición sectorial y orientación $\triangleright$ 
geográfica de las exportaciones disponibles en otras publicaciones que explotan los datos de Aduanas. Así, el Informe Mensual de Comercio Exterior, que publica la Secretaría de Estado de Comercio (SEC), permite conocer con gran detalle la distribución geográfica y por productos de los flujos del comercio exterior de bienes de España. No obstante, los datos de Aduanas, por sí mismos, no permiten caracterizar a las empresas que realizan la actividad comercial con el exterior. Para suplir esta falta de información, Aduanas cruza los datos de comercio exterior por operador con los del Directorio Central de Empresas (DIRCE) del Instituto Nacional de Estadística (INE) para explotar sus variables de clasificación, como la actividad económica principal o el tamaño, entre otras, y poder así conocer las características de la empresa que realiza operaciones de comercio exterior.

En el epígrafe 2 se ofrecerá una visión general de los exportadores españoles y del valor de lo exportado. Esta visión global permitirá enmarcar el análisis que se efectúa en los epígrafes 3 a 8, empleando datos de comercio declarado realizado por los exportadores que cruzan con el DIRCE (empresas exportadoras DIRCE, en adelante).

En los epígrafes 3 a 8 se irán analizando los rasgos de las empresas exportadoras DIRCE atendiendo a diferentes variables de clasificación y, cuando haya posibilidad, a cruces entre ellas. Estas variables son: el tamaño de la empresa según su número de asalariados, la actividad principal de la empresa según la Clasificación Nacional de Actividades Económicas (CNAE), los tramos de exportación, la concentración de las exportaciones, la regularidad y, por último, los destinos geográficos por zonas de intercambio y número de destinos.

El análisis se complementa, en el epígrafe 9, con una comparativa internacional analizando los datos de Eurostat, tanto para España como para los principales exportadores de la UE. Las tablas estadísticas están disponibles en la web de Eurostat en la operación International trade in goods - trade by enterprise characteristics (TEC). Estos datos presentan diferencias metodológicas importantes con respecto a los datos de Aduanas. Al final de este artículo se presenta un anexo metodológico que aborda con detalle estas diferencias metodológicas.

Con los datos de Eurostat se realizará, en primer lugar, una comparativa por países de la distribución del número de empresas exportadoras y valor de las exportaciones por tamaño de la empresa, para posteriormente, y a partir de estos datos, calcular la propensión exportadora. Otras dimensiones analizadas serán el tipo de propiedad de la empresa o si las empresas que exportan son al mismo tiempo importadoras.

Finalmente, en el último epígrafe se presentarán las conclusiones extraídas a partir del análisis de los cuadros presentados en este artículo.

El estudio es esencialmente de corte transversal con los datos de 2017, debido a que el análisis longitudinal a medio plazo se ve dificultado por la ruptura de la serie en 2015, derivada de la elevación del umbral de exención. No obstante, en la mayor parte de los cuadros se presentan también datos de otros años y la tasa de variación con respecto a 2016.

\section{Visión general}

En este apartado se presenta una visión global de los datos y conceptos que se emplean a lo largo del artículo. El objetivo es facilitar que el lector entienda los datos que permiten estudiar las características de las empresas exportadoras, comprenda las diferencias $\triangleright$ 
que se pueden observar entre estos datos y otros empleados habitualmente en el estudio de los flujos de comercio internacional y sea consciente de la potencia y limitaciones de alcance que puede tener el análisis de las características de las empresas exportadoras que se desarrolla en los siguientes epígrafes.

El concepto más amplio y menos restrictivo procedente de las estadísticas de Aduanas es el del exportador del comercio total, que incluye a cualquier operador, sea o no empresa, que haya realizado alguna operación de exportación en el año correspondiente. Bajo esta definición, en 2017 hubo en España 231.445 exportadores (Gráfico 1, Cuadros 1A y 1B). No obstante, se trata de una cifra poco relevante para el análisis de las características de las empresas que exportan, ya que incluye un elevado número de operadores que no son necesariamente empresas y que presentan, además, unas cifras de comercio poco significativas.

Un concepto más restrictivo es el de comercio declarado. En 2017 hubo 161.133 exportadores de comercio declarado ${ }^{1}$ que exportaron por valor de 276.143 millones, aproximadamente el $98 \%$ de las exportaciones totales. Aduanas obtiene estos datos directamente de los exportadores, ya sea a través de las declaraciones aduaneras (DUA) en el comercio extracomunitario o por medio de las declaraciones estadísticas (Intrastat) en el intracomunitario. Solo los operadores que superan el denominado umbral de exención están obligados a presentar declaraciones Intrastat. Gracias a estas declaraciones se conocen con detalle los importes, los productos exportados, así como el destino concreto de los mismos. Estos datos

\footnotetext{
En la evolución del comercio declarado en los últimos años debe tenerse en cuenta el impacto de la elevación del umbral de exención Intrastat desde 250.000 euros anuales en 2014 a 400.000 euros en 2015, que supuso una ruptura de la serie.
}

coinciden en valor y metodología con los que publica la SEC en el Informe Mensual de Comercio Exterior, que incluye un apartado de exportadores, y en la web de Datacomex (http://datacomex.comercio.es/), así como el ICEX en su Perfil de la Empresa Exportadora Española.

El origen de las diferencias entre comercio total y comercio declarado es que el comercio total incluye operaciones que no se declaran correspondientes principalmente al comercio intracomunitario realizado por operadores que no superan el umbral de exención y quedan, por tanto, eximidos de presentar las declaraciones estadísticas Intrastat. En menor medida también incluye operadores obligados, que no han presentado la declaración. Para calcular el comercio total, Aduanas estima el valor no declarado a partir de las declaraciones del IVA. De este comercio intracomunitario no declarado no se puede conocer ni el destino ni el producto comercializado. En 2017, Aduanas estimó la existencia de 96.015 operadores bajo umbral que exportaron a la UE por valor de 6.299 millones. Así, aunque el número de operadores bajo umbral es elevado, el importe de las operaciones que realizan es poco significativo, ya que apenas representan el $2 \%$ de las exportaciones totales. De estos operadores bajo umbral, 25.703 habían exportado simultáneamente fuera de la UE, exportaciones que sí fueron declaradas y por tanto contabilizadas en el comercio declarado.

Partiendo de los datos de comercio declarado y con el fin de identificar las características de las empresas exportadoras e importadoras españolas, Aduanas cruza los operadores de comercio exterior con el directorio central de empresas del INE (DIRCE), que incluye variables de clasificación como la actividad económica principal o el tamaño. Los operadores $\triangleright$ 
Subdirección General de Estudios y Evaluación de Instrumentos de Política Comercial

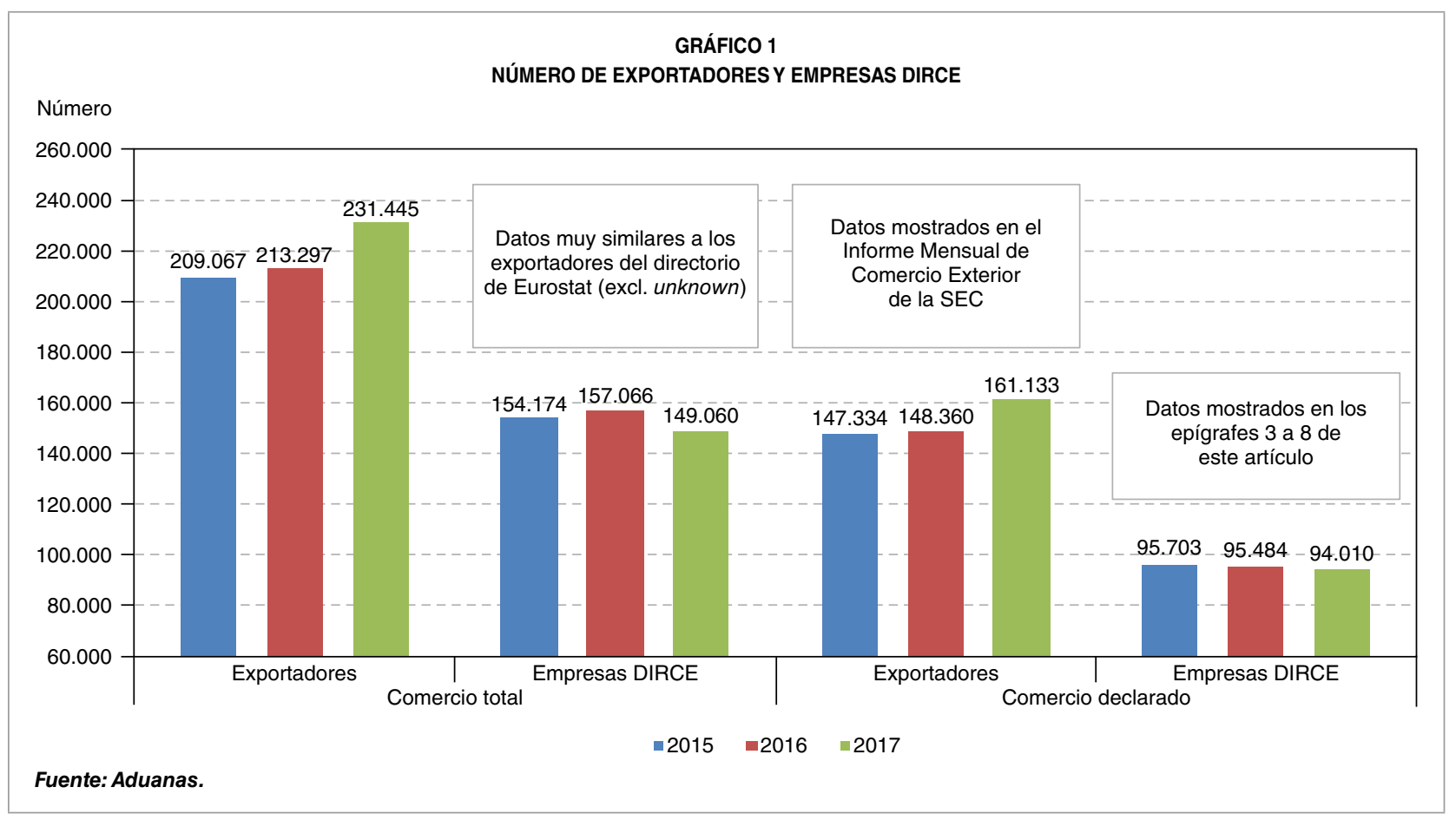

CUADRO $1 A$

NÚMERO DE EXPORTADORES Y EMPRESAS EXPORTADORAS DIRCE DE COMERCIO DECLARADOY TOTAL

\begin{tabular}{|c|c|c|c|c|c|c|c|c|c|}
\hline \multirow[b]{2}{*}{ Concepto } & \multicolumn{9}{|c|}{ Exportadores (número) } \\
\hline & 2010 & 2011 & 2012 & 2013 & 2014 & 2015 & 2016 & 2017 & $\begin{array}{c}\text { Variación } \\
\text { 2017/2016 (\%) }\end{array}$ \\
\hline Extra-UE (comercio declarado) & 97.607 & 111.784 & 125.995 & $\mid 139.072$ & 135.520 & 135.372 & 136.470 & 149.273 & 9,4 \\
\hline UE (comercio declarado) & 29.435 & 29.870 & 31.088 & 32.662 & 33.123 & 31.649 & 31.449 & 31.161 & $-0,9$ \\
\hline Comercio declarado & 109.363 & 123.128 & 137.528 & 151.160 & 147.845 & 147.334 & 148.360 & 161.133 & 8,6 \\
\hline UE (comercio estimado) & nd & nd & nd & nd & 80.185 & 87.938 & 90.626 & 96.015 & 5,9 \\
\hline Comercio total & nd & nd & 181.447 & 197.707 & 204.574 & 209.067 & 213.297 & 231.445 & 8,5 \\
\hline \multirow[b]{2}{*}{ Concepto } & \multicolumn{9}{|c|}{ Empresas exportadoras DIRCE (número) } \\
\hline & 2010 & 2011 & 2012 & 2013 & 2014 & 2015 & 2016 & 2017 & $\begin{array}{c}\text { Variación } \\
\text { 2017/2016 (\%) }\end{array}$ \\
\hline Extra-UE (comercio declarado) & 62.880 & 74.698 & 82.195 & 85.713 & 85.849 & 86.979 & 86.961 & 85.409 & $-1,8$ \\
\hline UE (comercio declarado) & 26.142 & 27.001 & 28.233 & 29.264 & 29.514 & 27.620 & 27.272 & 27.133 & $-0,5$ \\
\hline Comercio declarado DIRCE & 72.047 & 83.725 & 91.409 & 95.139 & 95.328 & 95.703 & 95.484 & 94.010 & $-1,5$ \\
\hline UE (comercio estimado) & nd & nd & nd & nd & nd & 84.412 & 87.064 & 80.580 & $-7,4$ \\
\hline Comercio total DIRCE & nd & nd & nd & nd & nd & 154.174 & 157.066 & 149.060 & $-5,1$ \\
\hline \multirow[b]{2}{*}{ Concepto } & \multicolumn{9}{|c|}{ Porcentaje de empresas exportadoras DIRCE sobre exportadores } \\
\hline & 2010 & 2011 & 2012 & 2013 & 2014 & 2015 & 2016 & 2017 & $\begin{array}{c}\text { Variación } \\
\text { 2017/2016 (pp) }\end{array}$ \\
\hline Extra-UE (comercio declarado) & 64,4 & 66,8 & 65,2 & 61,6 & 63,3 & 64,3 & 63,7 & 57,2 & $-6,5$ \\
\hline UE (comercio declarado) & 88,8 & 90,4 & 90,8 & 89,6 & 89,1 & 87,3 & 86,7 & 87,1 & 0,4 \\
\hline Comercio declarado & 65,9 & 68,0 & 66,5 & 62,9 & 64,5 & 65,0 & 64,4 & 58,3 & $-6,0$ \\
\hline Comercio total & nd & nd & nd & nd & nd & 73,7 & 73,6 & 64,4 & $-9,2$ \\
\hline
\end{tabular}


que están incluidos en el DIRCE son empresas en sentido amplio².

Las empresas exportadoras DIRCE explican un elevado porcentaje del comercio declarado (y también del comercio total). Así, en 2017, hubo 94.010 empresas exportadoras de comercio declarado que cruzaron con el DIRCE que exportaron por valor de 251.069 millones de euros. Si bien por número representaron únicamente el $58,3 \%$ de los exportadores de comercio declarado, su importancia en términos de valor es muy superior, un $90,9 \%$ (Gráfico 2).

Dada la mayor riqueza de análisis que permiten los datos de comercio declarado (productos, destinos...) y el elevado porcentaje de las exportaciones totales que suponen las empresas DIRCE que realizan comercio declarado, Aduanas analiza las características de las empresas españolas exportadoras o importadoras a partir de estas empresas DIRCE. En

2 Unidades incluidas en el DIRCE que realizan una actividad económica, pero no tienen necesariamente forma jurídica de empresa (p. ej., autónomos). consecuencia, todo el análisis de los epígrafes 3 a 8 versará sobre las empresas exportadoras DIRCE de comercio declarado.

Además, en los epígrafes que siguen se hará especial referencia a las características de los exportadores regulares, ya que resulta de especial interés, por sus implicaciones en la política de internacionalización, caracterizar a las empresas que exportan regularmente. Los exportadores regulares están muy presentes en el diseño de las políticas de internacionalización. Así, en la Estrategia de Internacionalización de la Economía Española 2017-2027 se incorporó como reto y objetivo específico el aumento de la base de empresas que exportan regularmente. Para ello se introdujo, dentro de las medidas de apoyo de carácter general, la elaboración de programas que permitiesen a las empresas abordar la actividad exportadora de forma más regular.

Se entiende por exportador regular (o estable, en terminología de Aduanas) aquel que ha exportado en el año de referencia y en cada uno de los tres años precedentes. Nuevamente $\square$

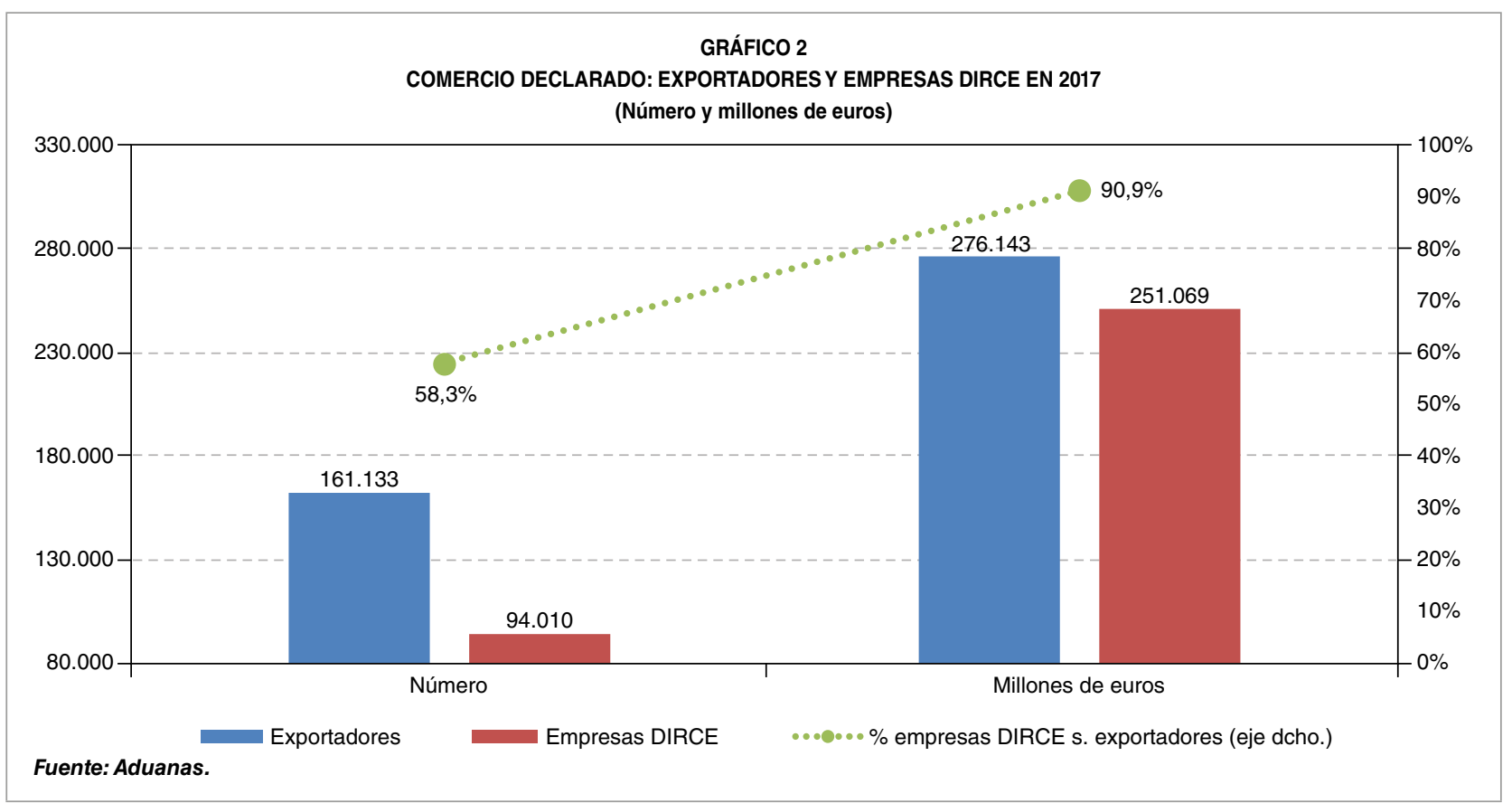


Subdirección General de Estudios y Evaluación de Instrumentos de Política Comercial

CUADRO 1B

VALOR DE LAS EXPORTACIONES DE EXPORTADORES Y EMPRESAS EXPORTADORAS DIRCE DE COMERCIO DECLARADOY TOTAL

\begin{tabular}{|c|c|c|c|c|c|c|c|c|c|}
\hline \multirow[b]{2}{*}{ Concepto } & \multicolumn{9}{|c|}{ Valor exportado por exportadores (millones de euros) } \\
\hline & 2010 & 2011 & 2012 & 2013 & 2014 & 2015 & 2016 & 2017 & $\begin{array}{c}\text { Variación } \\
\text { 2017/2016 (\%) }\end{array}$ \\
\hline Extra-UE (comercio declarado) & 60.489 & 72.871 & 83.115 & 88.093 & 87.735 & 88.075 & 86.093 & 94.758 & 10,1 \\
\hline UE (comercio declarado) & 126.291 & 142.359 & 143.000 & 147.722 & 152.847 & 161.719 & 170.300 & 181.385 & 6,5 \\
\hline Comercio declarado & 186.780 & 215.230 & 226.115 & 235.814 & 240.582 & 249.795 & 256.393 & 276.143 & 7,7 \\
\hline UE (comercio estimado) ${ }^{*}$ & nd & 4.494 & 3.260 & 2.938 & 3.078 & 4.005 & 4.810 & 6.299 & 31,0 \\
\hline Comercio total & nd & 219.725 & 229.374 & 238.752 & 243.660 & 253.799 & 261.203 & 282.442 & 8,1 \\
\hline \multirow[b]{2}{*}{ Concepto } & \multicolumn{9}{|c|}{ Valor exportado por empresas DIRCE (millones de euros) } \\
\hline & 2010 & 2011 & 2012 & 2013 & 2014 & 2015 & 2016 & 2017 & $\begin{array}{c}\text { Variación } \\
2017 / 2016(\%)\end{array}$ \\
\hline Extra-UE (comercio declarado) & 55.731 & 68.448 & 77.671 & 80.507 & 79.683 & 78.904 & 76.645 & 83.301 & 8,7 \\
\hline UE (comercio declarado) & 116.524 & 130.320 & 131.816 & 133.751 & 139.138 & 150.028 & 158.557 & 167.768 & 5,8 \\
\hline Comercio declarado DIRCE & 172.255 & 198.768 & 209.488 & 214.258 & 218.821 & 228.932 & 235.203 & 251.069 & 6,7 \\
\hline Comercio total DIRCE & nd & nd & nd & nd & nd & 232.131 & 238.471 & 254.769 & 6,8 \\
\hline \multirow[b]{2}{*}{ Concepto } & \multicolumn{9}{|c|}{ Porcentaje de valor exportado por empresas exportadoras DIRCE sobre exportadores } \\
\hline & 2010 & 2011 & 2012 & 2013 & 2014 & 2015 & 2016 & 2017 & $\begin{array}{c}\text { Variación } \\
\text { 2017/2016 (pp) }\end{array}$ \\
\hline Extra-UE (comercio declarado) & 92,1 & 93,9 & 93,5 & 91,4 & 90,8 & 89,6 & 89,0 & 87,9 & $-1,3$ \\
\hline UE (comercio declarado) & 92,3 & 91,5 & 92,2 & 90,5 & 91,0 & 92,8 & 93,1 & 92,5 & $-0,7$ \\
\hline Comercio declarado & 92,2 & 92,4 & 92,6 & 90,9 & 91,0 & 91,6 & 91,7 & 90,9 & $-0,9$ \\
\hline Comercio total & nd & nd & nd & nd & nd & 91,5 & 91,3 & 90,2 & $-1,2$ \\
\hline
\end{tabular}

aquí cabe distinguir entre operadores de comercio total y de comercio declarado y, dentro de estos, los que cruzan con el DIRCE.

Así, en 2017 hubo 50.568 exportadores regulares de comercio declarado que exportaron por valor de 262.515 millones. Si bien los exportadores regulares representaron únicamente el $31,4 \%$ de los exportadores de comercio declarado (161.133), abarcaron la práctica totalidad del valor exportado declarado $(95,1 \%$ del total o $96,4 \%$ si se restringe a las empresas DIRCE). La mayor parte de los exportadores regulares, $46.037(91,0 \%)$, cruzaron además con el DIRCE y estas empresas DIRCE fueron responsables del $92,2 \%$ de las exportaciones regulares de comercio declarado (Cuadro 2).
Se observa, por lo tanto, que las empresas DIRCE regulares determinan, en gran medida, el comportamiento del conjunto de empresas regulares, por lo que el estudio de sus características que se realizan en los siguientes epígrafes es relevante para el diseño de las políticas de apoyo a la internacionalización.

\section{Análisis de las empresas exportadoras DIRCE por estrato de asalariados}

La clasificación de las empresas exportadoras DIRCE en función de su número de asalariados permite categorizar las empresas por $D$ 
CUADRO 2

NÚMERO DE EXPORTADORES REGULARESY VALOR DE SUS EXPORTACIONES (COMERCIO DECLARADO)

\begin{tabular}{|c|c|c|c|c|c|c|c|c|c|}
\hline \multirow[b]{2}{*}{ Concepto } & \multicolumn{9}{|c|}{ Número de exportadores } \\
\hline & 2010 & 2011 & 2012 & 2013 & 2014 & 2015 & 2016 & 2017 & $\begin{array}{c}\text { Variación } \\
2017 / 2016(\%)\end{array}$ \\
\hline Exportadores regulares & 38.763 & 37.253 & 38.373 & 41.168 & 45.842 & 47.768 & 49.767 & 50.568 & 1,6 \\
\hline Empresas exportadoras regulares DIRCE & 35.428 & 35.983 & 37.008 & 38.419 & 41.887 & 43.699 & 45.487 & 46.037 & 1,2 \\
\hline $\begin{array}{l}\text { Empresas exportadoras regulares DIRCE } \\
\text { sobre exportadores regulares (\%) }\end{array}$ & 91,4 & 96,6 & 96,4 & 93,3 & 91,4 & 91,5 & 91,4 & 91,0 & $-0,4 p p$ \\
\hline \multirow[b]{2}{*}{ Concepto } & \multicolumn{9}{|c|}{ Valor (millones de euros) } \\
\hline & 2010 & 2011 & 2012 & 2013 & 2014 & 2015 & 2016 & 2017 & $\begin{array}{c}\text { Variación } \\
2017 / 2016(\%)\end{array}$ \\
\hline Exportadores regulares & 170.606 & 195.407 & 205.750 & 216.966 & 223.421 & 233.440 & 241.727 & 262.515 & 8,6 \\
\hline Empresas exportadoras regulares DIRCE & 160.291 & 185.813 & 194.555 & 201.207 & 207.005 & 218.290 & 225.661 & 242.019 & 7,2 \\
\hline $\begin{array}{l}\text { Empresas exportadoras regulares DIRCE } \\
\text { sobre exportadores regulares (\%) }\end{array}$ & 94,0 & 95,1 & 94,6 & 92,7 & 92,7 & 93,5 & 93,4 & 92,2 & $-0,2 p p$ \\
\hline
\end{tabular}

tamaño empleando los criterios fijados por la Comisión Europea ${ }^{3}$.

El análisis de las empresas exportadoras según su tamaño revela la importancia de las pymes en la base exportadora española, aunque su contribución al valor de lo exportado es menos significativa. Este predominio es menos acusado entre las empresas que exportan regularmente, ya que se observa una relación positiva entre regularidad y tamaño empresarial.

El número total de empresas exportadoras DIRCE descendió en un $1,5 \%$ en 2017. Esta evolución es resultado de un crecimiento sostenido del número de grandes empresas que exportan y de una reducción del número de pymes exportadoras, con mayor incidencia en las microempresas. No obstante, esta reducción en el número de empresas no ha venido acompañada por una reducción de las ventas exteriores, sino que en la evolución reciente se

3 Para las notaciones de tipología de empresa (microempresa, pequeña y mediana empresa o pyme) se utiliza la terminología de la Comisión Europea (Recomendación 2003/361/CE), aunque tomando únicamente en consideración el número de asalariados. Por exclusión, las empresas de 250 o más asalariados se considerarán gran empresa (https://eur-lex.europa.eu/legal-content/ES/TXT/?uri=LEGISSUM\%3An26026). observa un crecimiento continuado del valor exportado en todos los estratos de tamaño.

Las pymes, definidas como aquellas empresas que disponen de menos de 250 asalariados, representaron en 2017 la inmensa mayoría de las empresas exportadoras DIRCE de comercio declarado en España, en concreto 91.645, el 97,5\% del total (94.010), y aportaron aproximadamente la mitad del valor exportado $(50,1 \%)$. Dentro de estas destacaron en número las microempresas (de hasta 9 asalariados), que supusieron el $63,7 \%$ del total, aunque aportaron solo el $11,9 \%$ del valor exportado. En el extremo opuesto, las grandes empresas (de 250 o más asalariados), a pesar de representar únicamente el 2,5\% del total, fueron responsables de la otra mitad del valor exportado (49,9\%) (Cuadro 3).

En contraposición al descenso del número global de exportadores DIRCE, el número de empresas DIRCE que exportan de forma regular ha continuado aumentando en 2017, hasta alcanzar 46.037 (Cuadro 4A). Se observa, además, que la presencia de grandes empresas es mayor, tanto en el valor exportado $(50,9 \%) \triangleright$ 
Subdirección General de Estudios y Evaluación de Instrumentos de Política Comercial

CUADRO 3

NÚMERO DE EMPRESAS EXPORTADORAS DIRCE POR ESTRATO DE ASALARIADOS Y VALOR DE SUS EXPORTACIONES

(Comercio declarado)

\begin{tabular}{|c|c|c|c|c|c|c|c|c|c|c|}
\hline \multirow{2}{*}{$\begin{array}{l}\text { Estrato de } \\
\text { asalariados }\end{array}$} & \multicolumn{5}{|c|}{ Número de empresas exportadoras DIRCE } & \multicolumn{5}{|c|}{ Valor (millones de euros) } \\
\hline & 2010 & 2015 & 2016 & 2017 & $\begin{array}{c}\text { Variación } \\
2017 / 2016 \text { (\%) }\end{array}$ & 2010 & 2015 & 2016 & 2017 & $\begin{array}{c}\text { Variación } \\
2017 / 2016(\%)\end{array}$ \\
\hline 0-9 microempresa & 42.857 & 61.939 & 61.385 & 59.851 & $-2,5$ & 20.510 & 25.506 & 27.011 & 29.820 & 10,4 \\
\hline $10-49$ & 20.423 & 23.864 & 23.894 & 23.699 & $-0,8$ & 25.467 & 32.447 & 33.162 & 35.097 & 5,8 \\
\hline $50-199$ & 6.322 & 7.121 & 7.282 & 7.470 & 2,6 & 33.083 & 45.489 & 45.903 & 50.881 & 10,8 \\
\hline $200-249$ & 530 & 593 & 627 & 625 & $-0,3$ & 6.678 & 9.289 & 9.593 & 10.090 & 5,2 \\
\hline 0-249 pyme & 70.132 & 93.517 & 93.188 & 91.645 & $-1,7$ & 85.739 & 112.732 & 115.669 & 125.888 & 8,8 \\
\hline $250-499$ & 1.021 & 1.147 & 1.209 & 1.253 & 3,6 & 20.357 & 20.992 & 23.821 & 26.292 & 10,4 \\
\hline$>=500$ & 894 & 1.039 & 1.087 & 1.112 & 2,3 & 66.159 & 95.208 & 95.713 & 98.889 & 3,3 \\
\hline$>=250$ gran empresa & 1.915 & 2.186 & 2.296 & 2.365 & 3,0 & 86.516 & 116.200 & 119.534 & 125.181 & 4,7 \\
\hline Total & 72.047 & 95.703 & 95.484 & 94.010 & $-1,5$ & 172.255 & 228.932 & 235.203 & 251.069 & 6,7 \\
\hline \multirow{2}{*}{$\begin{array}{l}\text { Estrato de } \\
\text { asalariados }\end{array}$} & \multicolumn{5}{|c|}{$\begin{array}{c}\text { Porcentaje por estrato sobre el total de empresas } \\
\text { exportadoras DIRCE }\end{array}$} & \multicolumn{5}{|c|}{$\begin{array}{l}\text { Porcentaje por estrato sobre el valor } \\
\text { (millones de euros) }\end{array}$} \\
\hline & 2010 & 2015 & 2016 & 2017 & $\begin{array}{l}\text { Variación } \\
\text { 2017/2016 (pp) }\end{array}$ & 2010 & 2015 & 2016 & 2017 & $\begin{array}{l}\text { Variación } \\
\text { 2017/2016 (pp) }\end{array}$ \\
\hline 0-9 microempresa & 59,5 & 64,7 & 64,3 & 63,7 & $-0,6$ & 11,9 & 11,1 & 11,5 & 11,9 & 0,4 \\
\hline $10-49$ & 28,3 & 24,9 & 25,0 & 25,2 & 0,2 & 14,8 & 14,2 & 14,1 & 14,0 & $-0,1$ \\
\hline $50-199$ & 8,8 & 7,4 & 7,6 & 7,9 & 0,3 & 19,2 & 19,9 & 19,5 & 20,3 & 0,7 \\
\hline $200-249$ & 0,7 & 0,6 & 0,7 & 0,7 & 0,0 & 3,9 & 4,1 & 4,1 & 4,0 & $-0,1$ \\
\hline 0-249 pyme & 97,3 & 97,7 & 97,6 & 97,5 & $-0,1$ & 49,8 & 49,2 & 49,2 & 50,1 & 1,0 \\
\hline $250-499$ & 1,4 & 1,2 & 1,3 & 1,3 & 0,1 & 11,8 & 9,2 & 10,1 & 10,5 & 0,3 \\
\hline$>=500$ & 1,2 & 1,1 & 1,1 & 1,2 & 0,0 & 38,4 & 41,6 & 40,7 & 39,4 & $-1,3$ \\
\hline$>=250$ gran empresa & 2,7 & 2,3 & 2,4 & 2,5 & 0,1 & 50,2 & 50,8 & 50,8 & 49,9 & $-1,0$ \\
\hline Total & 100,0 & 100,0 & 100,0 & 100,0 & - & 100,0 & 100,0 & 100,0 & 100,0 & - \\
\hline
\end{tabular}

como sobre todo en el número de empresas $(4,1 \%)$. Simétricamente, las pymes representaron un porcentaje menor en las regulares, en especial por la menor regularidad mostrada por las microempresas, que en 2017 supusieron el 63,7 del total de empresas DIRCE, por tan solo el $47,7 \%$ de las regulares DIRCE.

La propensión a la regularidad tiende a aumentar con el tamaño de la empresa. Además, las empresas regulares son responsables de la práctica totalidad de las exportaciones realizadas por empresas DIRCE. La contribución de las empresas regulares al valor de la exportación aumenta en los estratos de mayor tamaño. Así, a partir de la información mostrada en los dos cuadros anteriores se puede calcular la proporción de empresas exportadoras DIRCE que exportan regularmente y el peso de sus exportaciones sobre el valor del comercio declarado (Cuadro 4B). Por estrato de asalariados se observa que la regularidad aumenta con el tamaño hasta estabilizarse alrededor del $80 \%$ en las medianas y grandes empresas. En cuanto al valor exportado, en media, el $96,4 \%$ es realizado por las empresas regulares, en la banda baja se encuentran las microempresas, con el $88,7 \%$, y en la banda alta, las empresas de 200 a 249 asalariados y las de más de 500 , con el $99,6 \%$ de las exportaciones realizadas por empresas regulares. $\quad \square$ 
CUADRO 4A

NÚMERO DE EMPRESAS EXPORTADORAS REGULARES DIRCE POR ESTRATO DE ASALARIADOSY VALOR DE SUS EXPORTACIONES

(Comercio declarado)

\begin{tabular}{|c|c|c|c|c|c|c|c|c|c|c|}
\hline \multirow{2}{*}{$\begin{array}{l}\text { Estrato de } \\
\text { asalariados }\end{array}$} & \multicolumn{5}{|c|}{ Número de empresas regulares DIRCE } & \multicolumn{5}{|c|}{ Valor de las exportaciones (millones de euros) } \\
\hline & 2010 & 2015 & 2016 & 2017 & $\begin{array}{c}\text { Variación } \\
2017 / 2016(\%)\end{array}$ & 2010 & 2015 & 2016 & 2017 & $\begin{array}{c}\text { Variación } \\
2017 / 2016(\%)\end{array}$ \\
\hline 0-9 microempresa & 15.624 & 20.935 & 21.957 & 21.938 & $-0,1$ & 15.354 & 21.157 & 23.568 & 26.445 & 12,2 \\
\hline $10-49$ & 13.116 & 15.125 & 15.620 & 15.855 & 1,5 & 22.858 & 29.802 & 31.002 & 33.194 & 7,1 \\
\hline $50-199$ & 4.771 & 5.401 & 5.584 & 5.834 & 4,5 & 31.509 & 42.896 & 43.886 & 49.160 & 12,0 \\
\hline $200-249$ & 424 & 476 & 501 & 508 & 1,4 & 6.548 & 9.040 & 8.511 & 10.048 & 18,1 \\
\hline 0-249 pyme & 33.935 & 41.937 & 43.662 & 44.135 & 1,1 & 76.269 & 102.895 & 106.967 & 118.848 & 11,1 \\
\hline $250-499$ & 809 & 927 & 971 & 1.005 & 3,5 & 19.892 & 20.566 & 23.591 & 24.702 & 4,7 \\
\hline$>=500$ & 684 & 835 & 854 & 897 & 5,0 & 64.130 & 94.829 & 95.103 & 98.470 & 3,5 \\
\hline$>=250$ gran empresa & 1.493 & 1.762 & 1.825 & 1.902 & 4,2 & 84.022 & 115.395 & 118.694 & 123.171 & 3,8 \\
\hline Total & 35.428 & 43.699 & 45.487 & 46.037 & 1,2 & 160.291 & 218.290 & 225.661 & 242.019 & 7,2 \\
\hline \multirow{2}{*}{$\begin{array}{l}\text { Estrato de } \\
\text { asalariados }\end{array}$} & \multicolumn{5}{|c|}{$\begin{array}{c}\text { Porcentaje por estrato sobre el total de empresas } \\
\text { exportadoras regulares DIRCE }\end{array}$} & \multicolumn{5}{|c|}{$\begin{array}{l}\text { Porcentaje por estrato sobre el valor total } \\
\text { de las exportaciones de empresas exportadoras } \\
\text { regulares DIRCE }\end{array}$} \\
\hline & 2010 & 2015 & 2016 & 2017 & $\begin{array}{l}\text { Variación } \\
2017 / 2016(p p)\end{array}$ & 2010 & 2015 & 2016 & 2017 & $\begin{array}{c}\text { Variación } \\
2017 / 2016(p p)\end{array}$ \\
\hline 0-9 microempresa & 44,1 & 47,9 & 48,3 & 47,7 & $-0,6$ & 9,6 & 9,7 & 10,4 & 10,9 & 0,5 \\
\hline $10-49$ & 37,0 & 34,6 & 34,3 & 34,4 & 0,1 & 14,3 & 13,7 & 13,7 & 13,7 & 0,0 \\
\hline $50-199$ & 13,5 & 12,4 & 12,3 & 12,7 & 0,4 & 19,7 & 19,7 & 19,4 & 20,3 & 0,9 \\
\hline $200-249$ & 1,2 & 1,1 & 1,1 & 1,1 & 0,0 & 4,1 & 4,1 & 3,8 & 4,2 & 0,4 \\
\hline 0-249 pyme & 95,8 & 96,0 & 96,0 & 95,9 & $-0,1$ & 47,6 & 47,1 & 47,4 & 49,1 & 1,7 \\
\hline $250-499$ & 2,3 & 2,1 & 2,1 & 2,2 & 0,0 & 12,4 & 9,4 & 10,5 & 10,2 & $-0,2$ \\
\hline$>=500$ & 1,9 & 1,9 & 1,9 & 1,9 & 0,1 & 40,0 & 43,4 & 42,1 & 40,7 & $-1,5$ \\
\hline$>=250$ gran empresa & 4,2 & 4,0 & 4,0 & 4,1 & 0,1 & 52,4 & 52,9 & 52,6 & 50,9 & $-1,7$ \\
\hline Total & 100,0 & 100,0 & 100,0 & 100,0 & - & 100,0 & 100,0 & 100,0 & 100,0 & - \\
\hline
\end{tabular}

CUADRO 4B

PORCENTAJE DE REGULARES SOBRE LAS EMPRESAS EXPORTADORAS DIRCE

(Comercio declarado)

\begin{tabular}{|c|c|c|c|c|c|c|c|c|c|c|}
\hline \multirow{2}{*}{$\begin{array}{l}\text { Estrato de } \\
\text { asalariados }\end{array}$} & \multicolumn{5}{|c|}{ En número de empresas DIRCE (\%) } & \multicolumn{5}{|c|}{ En valor de las exportaciones (\%) } \\
\hline & 2010 & 2015 & 2016 & 2017 & $\begin{array}{c}\text { Variación } \\
2017 / 2016(p p)\end{array}$ & 2010 & 2015 & 2016 & 2017 & $\begin{array}{c}\text { Variación } \\
2017 / 2016 \text { (pp) }\end{array}$ \\
\hline 0-9 microempresa & 36,5 & 33,8 & 35,8 & 36,7 & 0,9 & 74,9 & 82,9 & 87,3 & 88,7 & 1,4 \\
\hline $10-49$ & 64,2 & 63,4 & 65,4 & 66,9 & 1,5 & 89,8 & 91,8 & 93,5 & 94,6 & 1,1 \\
\hline $50-199$ & 75,5 & 75,8 & 76,7 & 78,1 & 1,4 & 95,2 & 94,3 & 95,6 & 96,6 & 1,0 \\
\hline $200-249$ & 80,0 & 80,3 & 79,9 & 81,3 & 1,4 & 98,1 & 97,3 & 88,7 & 99,6 & 10,9 \\
\hline 0-249 pyme & 48,4 & 44,8 & 46,9 & 48,2 & 1,3 & 89,0 & 91,3 & 92,5 & 94,4 & 1,9 \\
\hline $250-499$ & 79,2 & 80,8 & 80,3 & 80,2 & $-0,1$ & 97,7 & 98,0 & 99,0 & 93,9 & $-5,1$ \\
\hline$>=500$ & 76,5 & 80,4 & 78,6 & 80,7 & 2,1 & 96,9 & 99,6 & 99,4 & 99,6 & 0,2 \\
\hline$>=250$ gran empresa & 78,0 & 80,6 & 79,5 & 80,4 & 0,9 & 97,1 & 99,3 & 99,3 & 98,4 & $-0,9$ \\
\hline Total & 49,2 & 45,7 & 47,6 & 49,0 & 1,3 & 93,1 & 95,4 & 95,9 & 96,4 & 0,5 \\
\hline
\end{tabular}




\section{Análisis de la empresa exportadora DIRCE por actividad principal}

La base exportadora española está constituida principalmente por empresas comerciales y manufactureras. Resulta especialmente significativa la contribución de las empresas manufactureras al valor exportado. Este rasgo cobra mayor intensidad cuando el análisis se centra en las empresas que exportan de forma regular. Se constata, además, que las empresas manufactureras muestran una mayor propensión a la regularidad exportadora y que el predominio de la pyme exportadora es más acusado en el comercio que en la industria. En la industria, además, las empresas contabilizan valores medios de exportación más elevados.

Atendiendo a la actividad principal de la empresa, en 2017 el mayor número de empresas exportadoras correspondió al comercio (sección G de la CNAE 2009), con el $43,8 \%$ del total, debido especialmente a la división de comercio al por mayor, que por sí sola representó el $31,5 \%$ del total. En segundo lugar figura la industria manufacturera (sección $\mathrm{C}$ ), con el $27,4 \%$ de las empresas exportadoras DIRCE (Cuadro 5).

Las empresas de comercio y, especialmente, las manufactureras explican la práctica totalidad del valor de las exportaciones. Así, en 2017, el 95,6\% del valor de las exportaciones es atribuible a empresas cuya actividad principal estaba comprendida en estas dos secciones ( $C$ y $G)$, dejando un valor residual para el resto de actividades. En el valor de las exportaciones, la importancia de las aportaciones de la industria manufacturera y el comercio se invierte respecto a su peso en el número de empresas exportadoras. Así, las empresas de la industria manufacturera aglutinaron el $65,4 \%$ de las exportaciones totales, frente al $30,2 \%$ del comercio, con un $24,6 \%$ del total atribuible al comercio al por mayor.

Estos rasgos se intensifican cuando el análisis se centra en las empresas regulares. Así, entre las empresas exportadoras regulares DIRCE (Cuadro 6) dominan en número y con mayor peso las empresas del comercio $(45,4 \%)$, en especial las de la división de comercio al por mayor (37,4\%), y las correspondientes a la industria manufacturera $(37,9 \%)$. En lo que respecta al valor exportado, la industria manufacturera representa más de dos tercios de las exportaciones $(66,7 \%)$, por un $29,3 \%$ de las empresas del comercio, y dentro de estas, las del comercio al por mayor $(24,1 \%)$.

Las empresas manufactureras muestran una mayor propensión a la regularidad exportadora que las correspondientes a otras ramas de actividad. Así, el 67,6\% de las empresas exportadoras DIRCE de la industria manufacturera eran exportadores regulares, muy por encima de la media para el conjunto de actividades (49,0\%). En la sección comercio, el comportamiento fue muy dispar según se tratase de empresas exportadoras del comercio al por mayor, en el que el $58,1 \%$ exportaron regularmente, o del comercio al por menor, en el que solo el $27,9 \%$ lo hicieron.

En relación con el valor exportado, las empresas regulares DIRCE aglutinaron en su conjunto el 96,4\% del valor exportado por las empresas DIRCE. Este porcentaje fue incluso superior para las empresas de la industria manufacturera, que ascendió hasta el 98,3\%. Para el conjunto del comercio fue inferior, $93,7 \%$, y, dentro de este, también para el comercio al por mayor, $94,7 \%$.

El predominio de las pymes y, dentro de estas, de las microempresas, es más acusado $D$ 
CUADRO 5

NÚMERO DE EMPRESAS EXPORTADORAS DIRCE Y VALOR EXPORTADO (COMERCIO DECLARADO) POR ACTIVIDAD PRINCIPAL (CNAE 2009)

\begin{tabular}{|c|c|c|c|c|c|c|c|c|}
\hline \multirow{3}{*}{ CNAE-2009 } & \multicolumn{4}{|c|}{$\begin{array}{l}\text { Núm. de empresas exportadoras } \\
\text { DIRCE }\end{array}$} & \multicolumn{4}{|c|}{ Valor exportado } \\
\hline & \multicolumn{2}{|c|}{ Núm. empresas } & \multicolumn{2}{|c|}{ Peso s. total (\%) } & \multicolumn{2}{|c|}{ Millones de euros } & \multicolumn{2}{|c|}{ Peso s. total (\%) } \\
\hline & 2016 & 2017 & 2016 & 2017 & 2016 & 2017 & 2016 & 2017 \\
\hline A Agricultura, ganadería, silvicultura y pesca & 1.928 & 2.017 & 2,0 & 2,1 & 2.328 & 2.500 & 1,0 & 1,0 \\
\hline B Industrias extractivas & 220 & 221 & 0,2 & 0,2 & 676 & 820 & 0,3 & 0,3 \\
\hline C Industria manufacturera & 25.179 & 25.795 & 26,4 & 27,4 & 157.530 & 164.180 & 67,0 & 65,4 \\
\hline 10 Industria de la alimentación & 3.205 & 3.232 & 3,4 & 3,4 & 17.573 & 18.575 & 7,5 & 7,4 \\
\hline 11 Fabricación de bebidas & 1.917 & 2.000 & 2,0 & 2,1 & 2.391 & 2.546 & 1,0 & 1,0 \\
\hline 12 Industria del tabaco & 19 & 18 & 0,0 & 0,0 & 109 & 118 & 0,0 & 0,0 \\
\hline 13 Industria textil & 1.015 & 1.074 & 1,1 & 1,1 & 2.051 & 2.180 & 0,9 & 0,9 \\
\hline 14 Confección de prendas de vestir & 1.040 & 1.062 & 1,1 & 1,1 & 1.244 & 1.263 & 0,5 & 0,5 \\
\hline 15 Industria del cuero y del calzado & 932 & 973 & 1,0 & 1,0 & 1.676 & 1.689 & 0,7 & 0,7 \\
\hline 16 Ind. de la madera y del corcho, exc. muebles & 735 & 729 & 0,8 & 0,8 & 1.223 & 1.329 & 0,5 & 0,5 \\
\hline 17 Industria del papel & 482 & 488 & 0,5 & 0,5 & 3.110 & 3.282 & 1,3 & 1,3 \\
\hline 18 Artes gráficas y reprod. de soportes grabados & 912 & 922 & 1,0 & 1,0 & 650 & 608 & 0,3 & 0,2 \\
\hline 19 Coquerías y refino de petróleo & 8 & 10 & 0,0 & 0,0 & 6.858 & 8.904 & 2,9 & 3,5 \\
\hline 20 Industria química & 1.371 & 1.417 & 1,4 & 1,5 & 13.721 & 14.745 & 5,8 & 5,9 \\
\hline 21 Fabricación de productos farmacéuticos & 215 & 219 & 0,2 & 0,2 & 5.474 & 5.523 & 2,3 & 2,2 \\
\hline 22 Fabricación productos de caucho y plásticos & 1.406 & 1.422 & 1,5 & 1,5 & 6.162 & 6.577 & 2,6 & 2,6 \\
\hline 23 Fab. otros productos minerales no metálicos & 1.260 & 1.222 & 1,3 & 1,3 & 4.873 & 5.110 & 2,1 & 2,0 \\
\hline 24 Metalurgia; fab. productos de hierro, acero... & 430 & 440 & 0,5 & 0,5 & 11.999 & 13.416 & 5,1 & 5,3 \\
\hline 25 Fab. prod. metálicos, exc. maquinaria y equipo & 2.868 & 2.970 & 3,0 & 3,2 & 8.183 & 8.874 & 3,5 & 3,5 \\
\hline 26 Fab. prod. informáticos, electrónicos y ópticos & 667 & 662 & 0,7 & 0,7 & 1.551 & 1.607 & 0,7 & 0,6 \\
\hline 27 Fabricación de material y equipo eléctrico & 682 & 672 & 0,7 & 0,7 & 7.616 & 7.994 & 3,2 & 3,2 \\
\hline 28 Fabricación de maquinaria y equipo n.c.o.p. & 2.178 & 2.242 & 2,3 & 2,4 & 8.222 & 9.205 & 3,5 & 3,7 \\
\hline 29 Fab. de vehículos de motor, remolques... & 577 & 587 & 0,6 & 0,6 & 42.033 & 39.601 & 17,9 & 15,8 \\
\hline 30 Fabricación de otro material de transporte & 262 & 247 & 0,3 & 0,3 & 8.340 & 8.485 & 3,5 & 3,4 \\
\hline 31 Fabricación de muebles & 999 & 1.005 & 1,0 & 1,1 & 973 & 1.002 & 0,4 & 0,4 \\
\hline 32 Otras industrias manufactureras & 1.045 & 1.124 & 1,1 & 1,2 & 1.173 & 1.218 & 0,5 & 0,5 \\
\hline 33 Reparac. e instalación de maquinaria y equipo & 954 & 1.058 & 1,0 & 1,1 & 324 & 326 & 0,1 & 0,1 \\
\hline D Suministro de energía eléctrica, gas... & 78 & 78 & 0,1 & 0,1 & 387 & 505 & 0,2 & 0,2 \\
\hline E Suministro de agua, act. saneamiento & 304 & 322 & 0,3 & 0,3 & 426 & 505 & 0,2 & 0,2 \\
\hline F Construcción & 3.092 & 2.895 & 3,2 & 3,1 & 998 & 1.058 & 0,4 & 0,4 \\
\hline G Com. por mayor y menor; rep. vehículos & 40.905 & 41.155 & 42,8 & 43,8 & 67.511 & 75.781 & 28,7 & 30,2 \\
\hline 45 Venta y reparación de vehículos de motor... & 3.067 & 3.093 & 3,2 & 3,3 & 7.024 & 7.787 & 3,0 & 3,1 \\
\hline 46 Com. al por mayor e intermediarios del com. & 29.680 & 29.630 & 31,1 & 31,5 & 54.851 & 61.650 & 23,3 & 24,6 \\
\hline 47 Com. al por menor, exc. vehículos de motor... & 8.158 & 8.432 & 8,5 & 9,0 & 5.636 & 6.343 & 2,4 & 2,5 \\
\hline H Transporte y almacenamiento & 3.314 & 3.245 & 3,5 & 3,5 & 1.710 & 1.905 & 0,7 & 0,8 \\
\hline I Hostelería & 1.047 & 1.112 & 1,1 & 1,2 & 130 & 131 & 0,1 & 0,1 \\
\hline J Información y comunicaciones & 2.318 & 2.294 & 2,4 & 2,4 & 750 & 796 & 0,3 & 0,3 \\
\hline K Actividades financieras y de seguros & 432 & 384 & 0,5 & 0,4 & 238 & 342 & 0,1 & 0,1 \\
\hline L Actividades inmobiliarias & 644 & 578 & 0,7 & 0,6 & 61 & 47 & 0,0 & 0,0 \\
\hline M Act. profesionales, científicas y técnicas & 5.597 & 5.685 & 5,9 & 6,0 & 1.384 & 1.406 & 0,6 & 0,6 \\
\hline N Act. administrativas y servicios auxiliares & 3.062 & 2.821 & 3,2 & 3,0 & 951 & 941 & 0,4 & 0,4 \\
\hline O Admón. pública y defensa; SS obligatoria & 146 & 133 & 0,2 & 0,1 & 9 & 2 & 0,0 & 0,0 \\
\hline P Educación & 827 & 817 & 0,9 & 0,9 & 13 & 12 & 0,0 & 0,0 \\
\hline Q Act. sanitarias y de servicios sociales & 3.417 & 1.326 & 3,6 & 1,4 & 16 & 25 & 0,0 & 0,0 \\
\hline R Act. artísticas, recreativas y entretenimiento & 1.233 & 1.349 & 1,3 & 1,4 & 34 & 38 & 0,0 & 0,0 \\
\hline S Otros servicios & 1.281 & 1.270 & 1,3 & 1,4 & 48 & 54 & 0,0 & 0,0 \\
\hline T Actividades de los hogares... & 405 & 457 & 0,4 & 0,5 & 2 & 6 & 0,0 & 0,0 \\
\hline U Act. de organizaciones extraterritoriales & 55 & 56 & 0,1 & 0,1 & 1 & 14 & 0,0 & 0,0 \\
\hline Total & 95.484 & 94.010 & 100,0 & 100,0 & 235.203 & 251.069 & 100,0 & 100,0 \\
\hline
\end{tabular}


CUADRO 6

NÚMERO DE EMPRESAS EXPORTADORAS REGULARES Y TOTALES DIRCE Y VALOR DE SUS EXPORTACIONES (COMERCIO DECLARADO) POR ACTIVIDAD PRINCIPAL (CNAE 2009) EN 2017

\begin{tabular}{|c|c|c|c|c|c|c|}
\hline \multirow{2}{*}{ Secciones de la CNAE-2009 } & \multicolumn{3}{|c|}{$\begin{array}{l}\text { Núm. de empresas exportardoras } \\
\text { DIRCE }\end{array}$} & \multicolumn{3}{|c|}{$\begin{array}{l}\text { Valor exportaciones } \\
\text { (millones de euros) }\end{array}$} \\
\hline & Regulares & $\begin{array}{l}\% \text { s. total } \\
\text { regulares }\end{array}$ & $\begin{array}{l}\text { Regulares } \\
\text { s. total (\%) }\end{array}$ & Regulares & $\begin{array}{l}\% \text { s. total } \\
\text { regulares }\end{array}$ & $\begin{array}{l}\text { Regulares } \\
\text { s. total (\%) }\end{array}$ \\
\hline A Agricultura, ganadería, silvicultura y pesca & 944 & 2,1 & 46,8 & 2.253 & 0,9 & 90,1 \\
\hline B Industrias extractivas & 128 & 0,3 & 57,9 & 808 & 0,3 & 98,6 \\
\hline C Industria manufacturera & 17.443 & 37,9 & 67,6 & 161.369 & 66,7 & 98,3 \\
\hline 10 Industria de la alimentación & 2.359 & 5,1 & 73,0 & 18.243 & 7,5 & 98,2 \\
\hline 11 Fabricación de bebidas & 1.479 & 3,2 & 74,0 & 2.444 & 1,0 & 96,0 \\
\hline 12 Industria del tabaco & 14 & 0,0 & 77,8 & 118 & 0,0 & 99,9 \\
\hline 13 Industria textil & 704 & 1,5 & 65,5 & 2.067 & 0,9 & 94,8 \\
\hline 14 Confección de prendas de vestir & 585 & 1,3 & 55,1 & 1.243 & 0,5 & 98,4 \\
\hline 15 Industria del cuero y del calzado & 661 & 1,4 & 67,9 & 1.627 & 0,7 & 96,4 \\
\hline 16 Ind. de la madera y del corcho, exc. muebles & 434 & 0,9 & 59,5 & 1.274 & 0,5 & 95,9 \\
\hline 17 Industria del papel & 372 & 0,8 & 76,2 & 3.227 & 1,3 & 98,3 \\
\hline 18 Artes gráficas y reprod. de soportes grabados & 436 & 0,9 & 47,3 & 596 & 0,2 & 98,0 \\
\hline 19 Coquerías y refino de petróleo & 9 & 0,0 & 90,0 & 8.902 & 3,7 & 100,0 \\
\hline 20 Industria química & 1.082 & 2,4 & 76,4 & 14.084 & 5,8 & 95,5 \\
\hline 21 Fabricación de productos farmacéuticos & 188 & 0,4 & 85,8 & 5.513 & 2,3 & 99,8 \\
\hline 22 Fabricación de productos de caucho y plásticos & 1.074 & 2,3 & 75,5 & 6.467 & 2,7 & 98,3 \\
\hline 23 Fab. de otros productos minerales no metálicos & 795 & 1,7 & 65,1 & 5.033 & 2,1 & 98,5 \\
\hline 24 Metalurgia; fab. productos de hierro, acero... & 359 & 0,8 & 81,6 & 13.350 & 5,5 & 99,5 \\
\hline 25 Fab. de prod. metálicos, exc. maquinaria y equipo & 1.916 & 4,2 & 64,5 & 8.570 & 3,5 & 96,6 \\
\hline 26 Fab. de prod. informáticos, electrónicos y ópticos & 452 & 1,0 & 68,3 & 1.576 & 0,7 & 98,1 \\
\hline 27 Fabricación de material y equipo eléctrico & 514 & 1,1 & 76,5 & 7.869 & 3,3 & 98,4 \\
\hline 28 Fabricación de maquinaria y equipo n.c.o.p. & 1.675 & 3,6 & 74,7 & 8.919 & 3,7 & 96,9 \\
\hline 29 Fab. de vehículos de motor, remolques ... & 468 & 1,0 & 79,7 & 39.439 & 16,3 & 99,6 \\
\hline 30 Fabricación de otro material de transporte & 171 & 0,4 & 69,2 & 8.454 & 3,5 & 99,6 \\
\hline 31 Fabricación de muebles & 602 & 1,3 & 59,9 & 868 & 0,4 & 86,6 \\
\hline 32 Otras industrias manufactureras & 621 & 1,3 & 55,2 & 1.198 & 0,5 & 98,3 \\
\hline 33 Reparación e instalación de maquinaria y equipo & 473 & 1,0 & 44,7 & 288 & 0,1 & 88,5 \\
\hline D Suministro de energía eléctrica, gas... & 32 & 0,1 & 41,0 & 481 & 0,2 & 95,3 \\
\hline E Suministro de agua, act. saneamiento & 171 & 0,4 & 53,1 & 482 & 0,2 & 95,5 \\
\hline F Construcción & 738 & 1,6 & 25,5 & 923 & 0,4 & 87,2 \\
\hline G Com. por mayor y menor; rep. vehículos & 20.891 & 45,4 & 50,8 & 70.977 & 29,3 & 93,7 \\
\hline 45 Venta y reparación de vehículos de motor... & 1.329 & 2,9 & 43,0 & 7.448 & 3,1 & 95,6 \\
\hline 46 Com. al por mayor e intermediarios del comercio & 17.209 & 37,4 & 58,1 & 58.395 & 24,1 & 94,7 \\
\hline 47 Com. al por menor, exc. de vehículos de motor... & 2.353 & 5,1 & 27,9 & 5.133 & 2,1 & 80,9 \\
\hline H Transporte y almacenamiento & 834 & 1,8 & 25,7 & 1.817 & 0,8 & 95,4 \\
\hline I Hostelería & 209 & 0,5 & 18,8 & 125 & 0,1 & 96,0 \\
\hline $\mathrm{J}$ Información y comunicaciones & 913 & 2,0 & 39,8 & 769 & 0,3 & 96,6 \\
\hline K Actividades financieras y de seguros & 82 & 0,2 & 21,4 & 11 & 0,0 & 3,1 \\
\hline L Actividades inmobiliarias & 110 & 0,2 & 19,0 & 15 & 0,0 & 30,9 \\
\hline M Act. profesionales, científicas y técnicas & 1.701 & 3,7 & 29,9 & 1.107 & 0,5 & 78,7 \\
\hline N Act. administrativas y servicios auxiliares & 677 & 1,5 & 24,0 & 761 & 0,3 & 80,9 \\
\hline O Admón. pública y defensa; SS obligatoria & 63 & 0,1 & 47,4 & 2 & 0,0 & 84,8 \\
\hline P Educación & 195 & 0,4 & 23,9 & 5 & 0,0 & 39,7 \\
\hline Q Act. sanitarias y de servicios sociales & 368 & 0,8 & 27,8 & 24 & 0,0 & 94,5 \\
\hline R Act. artísticas, recreativas y entretenimiento & 224 & 0,5 & 16,6 & 30 & 0,0 & 79,9 \\
\hline S Otros servicios & 285 & 0,6 & 22,4 & 45 & 0,0 & 84,1 \\
\hline T Actividades de los hogares... & 10 & 0,0 & 2,2 & 0 & 0,0 & 0,6 \\
\hline U Act. de organizaciones extraterritoriales & 19 & 0,0 & 33,9 & 14 & 0,0 & 97,9 \\
\hline Total & 46.037 & 100,0 & 49,0 & 242.019 & 100,0 & 96,4 \\
\hline
\end{tabular}


en el comercio que en la industria. En este sentido, al realizar el cruce de tamaño y sector, se aprecian claras diferencias entre las empresas cuya actividad principal corresponde a la industria en sentido amplio (secciones B, C, D y
E de la CNAE 2009) o al comercio (sección G) (Cuadro 7). En la distribución de las empresas por estratos de asalariados, se observa que en ambos casos dominaron las pymes, 96,9\% en la industria y $98,8 \%$ para el comercio. No $\triangleright$

CUADRO 7

NÚMERO DE EMPRESAS EXPORTADORAS DIRCE Y VALOR EXPORTADO (COMERCIO DECLARADO) POR ESTRATO DE ASALARIADOS Y ACTIVIDAD ECONÓMICA EN 2017

\begin{tabular}{|c|c|c|c|c|c|c|c|c|}
\hline \multirow{2}{*}{$\begin{array}{l}\text { Estrato de } \\
\text { asalariados }\end{array}$} & \multicolumn{4}{|c|}{ Número de empresas } & \multicolumn{4}{|c|}{ Valor exportado (millones de euros) } \\
\hline & $\begin{array}{l}\text { Industria } \\
\text { (BCDE) }\end{array}$ & $\begin{array}{l}\text { Comercio } \\
\text { (G) }\end{array}$ & Resto & Total & $\begin{array}{l}\text { Industria } \\
\text { (BCDE) }\end{array}$ & $\begin{array}{l}\text { Comercio } \\
\text { (G) }\end{array}$ & Resto & Total \\
\hline 0-9 microempresa & 10.848 & 30.893 & 18.110 & 59.851 & 4.869 & 23.408 & 1.543 & 29.820 \\
\hline $10-49$ & 10.919 & 7.668 & 5.112 & 23.699 & 17.701 & 15.172 & 2.224 & 35.097 \\
\hline $50-199$ & 3.541 & 1.974 & 1.955 & 7.470 & 36.007 & 12.839 & 2.036 & 50.881 \\
\hline $200-249$ & 284 & 140 & 201 & 625 & 8.004 & 1.903 & 183 & 10.090 \\
\hline 0-249 pyme & 25.592 & 40.675 & 25.378 & 91.645 & 66.580 & 53.322 & 5.986 & 125.888 \\
\hline $250-499$ & 519 & 271 & 463 & 1.253 & 20.414 & 5.156 & 721 & 26.292 \\
\hline 500 o más & 305 & 209 & 598 & 1.112 & 79.015 & 17.302 & 2.572 & 98.889 \\
\hline >=250 gran empresa & 824 & 480 & 1.061 & 2.365 & 99.429 & 22.459 & 3.293 & 125.181 \\
\hline Total declarado DIRCE & 26.416 & 41.155 & 26.439 & 94.010 & 166.010 & 75.781 & 9.279 & 251.069 \\
\hline \multirow{2}{*}{$\begin{array}{l}\text { Estrato de } \\
\text { asalariados }\end{array}$} & \multicolumn{4}{|c|}{$\begin{array}{l}\text { Porcentaje de número de empresas } \\
\text { sobre el total de la columna }\end{array}$} & \multicolumn{4}{|c|}{$\begin{array}{l}\text { Porcentaje de valor exportado } \\
\text { sobre total de la columna }\end{array}$} \\
\hline & $\begin{array}{l}\text { Industria } \\
\text { (BCDE) }\end{array}$ & $\begin{array}{l}\text { Comercio } \\
\text { (G) }\end{array}$ & Resto & Total & $\begin{array}{l}\text { Industria } \\
\text { (BCDE) }\end{array}$ & $\begin{array}{l}\text { Comercio } \\
\text { (G) }\end{array}$ & Resto & Total \\
\hline 0-9 microempresa & 41,1 & 75,1 & 68,5 & 63,7 & 2,9 & 30,9 & 16,6 & 11,9 \\
\hline $10-49$ & 41,3 & 18,6 & 19,3 & 25,2 & 10,7 & 20,0 & 24,0 & 14,0 \\
\hline $50-199$ & 13,4 & 4,8 & 7,4 & 7,9 & 21,7 & 16,9 & 21,9 & 20,3 \\
\hline $200-249$ & 1,1 & 0,3 & 0,8 & 0,7 & 4,8 & 2,5 & 2,0 & 4,0 \\
\hline 0-249 pyme & 96,9 & 98,8 & 96,0 & 97,5 & 40,1 & 70,4 & 64,5 & 50,1 \\
\hline $250-499$ & 2,0 & 0,7 & 1,8 & 1,3 & 12,3 & 6,8 & 7,8 & 10,5 \\
\hline 500 o más & 1,2 & 0,5 & 2,3 & 1,2 & 47,6 & 22,8 & 27,7 & 39,4 \\
\hline$>=250$ gran empresa & 3,1 & 1,2 & 4,0 & 2,5 & 59,9 & 29,6 & 35,5 & 49,9 \\
\hline \multirow[t]{12}{*}{ Total declarado DIRCE } & 100,0 & 100,0 & 100,0 & 100,0 & 100,0 & 100,0 & 100,0 & 100,0 \\
\hline & \multirow{2}{*}{\multicolumn{2}{|c|}{ Estrato de asalariados }} & \multicolumn{4}{|c|}{$\begin{array}{l}\text { Valor medio exportado por empresas } \\
\text { (millones de euros) }\end{array}$} & & \\
\hline & & & $\begin{array}{c}\text { Industria } \\
\text { (BCDE) }\end{array}$ & $\begin{array}{l}\text { Comercio } \\
\text { (G) }\end{array}$ & Resto & Total & & \\
\hline & 0-9 micro & mpresa & 0,4 & 0,8 & 0,1 & 0,5 & & \\
\hline & $10-49$ & & 1,6 & 2,0 & 0,4 & 1,5 & & \\
\hline & $50-199$ & & 10,2 & 6,5 & 1,0 & 6,8 & & \\
\hline & $200-249$ & & 28,2 & 13,6 & 0,9 & 16,1 & & \\
\hline & 0-249 pyme & & 2,6 & 1,3 & 0,2 & 1,4 & & \\
\hline & $250-499$ & & 39,3 & 19,0 & 1,6 & 21,0 & & \\
\hline & 500 o má & & 259,1 & 82,8 & 4,3 & 88,9 & & \\
\hline & $>=250$ gran & empresa & 120,7 & 46,8 & 3,1 & 52,9 & & \\
\hline & Total decla & ado DIRCE & 6,3 & 1,8 & 0,4 & 2,7 & & \\
\hline
\end{tabular}


obstante, dentro de las pymes las diferencias son sustanciales, ya que en el comercio las microempresas destacaron con el $75,1 \%$ del total de empresas ( $41,1 \%$ en la industria), mientras que en la industria predominaron las pequeñas y medianas con el $55,8 \%$ del total $(23,8 \%$ en el comercio). En el extremo opuesto, el peso de la gran empresa en la industria $(3,1 \%)$ prácticamente triplicó el del comercio (1,2\%).

Estas diferencias son más marcadas cuando se analiza la contribución al valor de las exportaciones. Así, la mayor parte del valor exportado en la industria $(59,9 \%)$ lo realizaron las grandes empresas, que representaron únicamente el 3,1\% de las empresas exportadoras de la industria, mientras que en el comercio fueron las pymes las que aglutinaron el $70,4 \%$ de las exportaciones, destacando el papel de las microempresas (30,9\% en valor), frente al 2,9\% del valor en la industria. Las grandes empresas de la industria, a pesar de representar menos de un $1 \%$ del total de las empresas exportadoras DIRCE de comercio declarado, fueron responsables del $40 \%$ del total de las exportaciones.

Al analizar el valor medio exportado, se observa que las empresas industriales en promedio exportaron más que las del comercio, 6,3 millones, frente a 1,8 millones. Este hecho también se repitió en todos los tramos, excepto en las microempresas exportadoras DIRCE, donde las del comercio exportaron en media casi el doble que las de la industria, 0,8 millones, frente a 0,4 millones, y en las pequeñas empresas (10-49 asalariados), aunque con una diferencia menor. A medida que va aumentando el tamaño, la diferencia en favor de la industria va incrementándose. Así, en la gran empresa, las empresas exportadoras industriales exportaron de media 2,6 veces lo exportado por las pertenecientes al comercio.
En resumen, en el número de empresas exportadoras dominan las comerciales, seguidas a distancia de la industria manufacturera, mientras que este orden se invierte en lo que respecta al volumen exportado. Las empresas de la industria manufacturera mostraron una regularidad muy superior a la del conjunto de empresas y también a las de comercio, aunque dentro de estas las empresas de comercio al por mayor mostraron una regularidad muy superior a la media, mientras que la regularidad de las de comercio al por menor fue muy inferior. En el cruce del sector con el tamaño, la mayor parte del valor exportado en la industria lo realizaron las grandes empresas, mientras que en el comercio las pymes dominaron, con especial presencia de las microempresas.

\section{Análisis de la concentración de las exportaciones por principales empresas exportadoras DIRCE}

Las principales empresas exportadoras DIRCE representan un porcentaje muy elevado de las exportaciones. Esta elevada concentración se repite con independencia de la zona de destino de la exportación (UE o extra-UE) o de la actividad principal de las empresas (industria, comercio o resto).

Así, en 2017 las mil principales empresas exportadoras DIRCE concentraron más de dos tercios de la exportación (67,5\%), porcentaje similar al de los dos años anteriores, pero inferior al correspondiente al año 2010 (70,7\%). Asimismo, las cincuenta principales empresas exportadoras fueron responsables de más de una tercera parte de las exportaciones (33,7\%), porcentaje algo inferior al correspondiente al del año precedente (34,3\%) y al del año 2010 $(34,0 \%)$ (Cuadro 8). 
CUADRO 8

CONCENTRACIÓN DE LAS EXPORTACIONES (COMERCIO DECLARADO) DE LAS EMPRESAS DIRCE POR ZONA DE INTERCAMBIO

\begin{tabular}{|c|c|c|c|c|c|c|c|c|c|}
\hline \multirow[b]{2}{*}{ N..$^{\circ}$ de empresas DIRCE } & \multicolumn{4}{|c|}{ Valor (millones de euros) } & \multicolumn{5}{|c|}{ Porcentaje sobre el total de cada zona de intercambio } \\
\hline & 2010 & 2015 & 2016 & 2017 & 2010 & 2015 & 2016 & 2017 & $\begin{array}{c}\text { Variación } \\
\text { 2017/2016 (pp) }\end{array}$ \\
\hline \multicolumn{10}{|c|}{ Total } \\
\hline 5 principales empresas & 20.477 & 26.070 & 28.542 & 28.540 & 11,9 & 11,4 & 12,1 & 11,4 & $-0,8$ \\
\hline 10 principales empresas & 29.613 & 39.427 & 40.903 & 41.857 & 17,2 & 17,2 & 17,4 & 16,7 & $-0,7$ \\
\hline 20 principales empresas & 41.158 & 55.164 & 57.750 & 59.813 & 23,9 & 24,1 & 24,6 & 23,8 & $-0,7$ \\
\hline 50 principales empresas & 58.581 & 77.514 & 80.669 & 84.682 & 34,0 & 33,9 & 34,3 & 33,7 & $-0,6$ \\
\hline 100 principales empresas & 71.335 & 93.201 & 96.858 & 102.937 & 41,4 & 40,7 & 41,2 & 41,0 & $-0,2$ \\
\hline 500 principales empresas & 105.212 & 133.961 & 138.244 & 147.254 & 61,1 & 58,5 & 58,8 & 58,7 & $-0,1$ \\
\hline 1.000 principales empresas & 121.719 & 154.328 & 158.855 & 169.538 & 70,7 & 67,4 & 67,5 & 67,5 & 0,0 \\
\hline Total empresas DIRCE & 172.255 & 228.932 & 235.203 & 251.069 & 100,0 & 100,0 & 100,0 & 100,0 & - \\
\hline \multicolumn{10}{|c|}{ Unión Europea } \\
\hline 5 principales empresas & 14.964 & 20.241 & 22.624 & 22.243 & 12,8 & 13,5 & 14,3 & 13,3 & $-1,0$ \\
\hline 10 principales empresas & 20.864 & 29.895 & 32.915 & 33.076 & 17,9 & 19,9 & 20,8 & 19,7 & $-1,0$ \\
\hline 20 principales empresas & 27.489 & 39.929 & 44.291 & 45.205 & 23,6 & 26,6 & 27,9 & 26,9 & $-1,0$ \\
\hline 50 principales empresas & 37.471 & 52.880 & 58.618 & 61.105 & 32,2 & 35,3 & 37,0 & 36,4 & $-0,5$ \\
\hline 100 principales empresas & 45.641 & 62.748 & 69.286 & 72.469 & 39,2 & 41,9 & 43,7 & 43,2 & $-0,5$ \\
\hline 500 principales empresas & 68.359 & 90.032 & 97.105 & 102.213 & 58,7 & 60,1 & 61,2 & 60,9 & $-0,3$ \\
\hline 1.000 principales empresas & 79.904 & 103.868 & 111.350 & 117.409 & 68,6 & 69,3 & 70,2 & 70,0 & $-0,2$ \\
\hline Total empresas DIRCE & 116.524 & 149.887 & 158.557 & 167.768 & 100,0 & 100,0 & 100,0 & 100,0 & - \\
\hline \multicolumn{10}{|c|}{ Terceros países } \\
\hline 5 principales empresas & 5.513 & 8.384 & 7.856 & 9.099 & 9,9 & 10,6 & 10,3 & 10,9 & 0,7 \\
\hline 10 principales empresas & 8.749 & 13.642 & 12.246 & 13.430 & 15,7 & 17,3 & 16,0 & 16,1 & 0,1 \\
\hline 20 principales empresas & 13.669 & 19.809 & 17.976 & 19.131 & 24,5 & 25,1 & 23,5 & 23,0 & $-0,5$ \\
\hline 50 principales empresas & 21.110 & 28.488 & 25.702 & 28.986 & 37,9 & 36,1 & 33,5 & 34,8 & 1,3 \\
\hline 100 principales empresas & 25.694 & 35.031 & 32.482 & 35.961 & 46,1 & 44,4 & 42,4 & 43,2 & 0,8 \\
\hline 500 principales empresas & 36.854 & 50.813 & 48.132 & 52.799 & 66,1 & 64,4 & 62,8 & 63,4 & 0,6 \\
\hline 1.000 principales empresas & 41.816 & 57.904 & 55.141 & 60.280 & 75,0 & 73,4 & 71,9 & 72,4 & 0,4 \\
\hline Total empresas DIRCE & 55.731 & 78.904 & 76.645 & 83.301 & 100,0 & 100,0 & 100,0 & 100,0 & - \\
\hline
\end{tabular}

La concentración se puede analizar según la zona de destino, ya sea intra-UE o extra-UE. Así, el comercio intracomunitario muestra una mayor concentración de las exportaciones hasta las cincuenta primeras empresas, muy similar en las cien primeras e inferior a medida que aumenta el número de empresas principales.

Por actividades económicas (Cuadro 9), en 2017 las quinientas principales empresas tanto en el conjunto de la industria (secciones B, C, D y E de la CNAE 2009) como en el comercio (sección $\mathrm{G}$ ) fueron responsables de algo más de dos tercios de las exportaciones de cada sector $(67,5 \%$ para la industria y $67,8 \%$ para el comercio). Por debajo de ese número de empresas del comercio presentaron un mayor grado de concentración en las exportaciones, mientras que, por encima, las mil principales de la industria presentaron un mayor porcentaje de les exportaciones (77,3\% frente al $76,2 \%$ del comercio). Más de la mitad de las exportaciones de comercio declarado de empresas DIRCE $(51,1 \%)$ lo realizaron las mil principales empresas de la industria. 
Subdirección General de Estudios y Evaluación de Instrumentos de Política Comercial

CUADRO 9

CONCENTRACIÓN DE LAS EXPORTACIONES (COMERCIO DECLARADO) DE LAS EMPRESAS DIRCE POR NÚMERO DE EMPRESAS Y ACTIVIDAD PRINCIPAL EN 2017

\begin{tabular}{|c|c|c|c|c|c|c|c|c|}
\hline \multirow[b]{2}{*}{ N. ${ }^{\circ}$ de empresas DIRCE } & \multicolumn{4}{|c|}{ Valor de las exportaciones (millones de euros) } & \multicolumn{4}{|c|}{ Porcentaje sobre total actividad } \\
\hline & $\begin{array}{c}\text { Industria } \\
\text { (BCDE) }\end{array}$ & $\begin{array}{c}\text { Comercio } \\
\text { (G) }\end{array}$ & $\begin{array}{c}\text { Resto } \\
\text { actividades }\end{array}$ & Total & $\begin{array}{c}\text { Industria } \\
\text { (BCDE) }\end{array}$ & $\begin{array}{c}\text { Comercio } \\
\text { (G) }\end{array}$ & $\begin{array}{c}\text { Resto } \\
\text { actividades }\end{array}$ & Total \\
\hline 5 principales empresas & 25.331 & 14.538 & 2.018 & 28.540 & 15,3 & 19,2 & 21,7 & 11,4 \\
\hline 10 principales empresas & 37.338 & 19.534 & 2.750 & 41.857 & 22,5 & 25,8 & 29,6 & 16,7 \\
\hline 20 principales empresas & 51.248 & 25.414 & 3.399 & 59.813 & 30,9 & 33,5 & 36,6 & 23,8 \\
\hline 50 principales empresas & 68.030 & 32.398 & 4.424 & 84.682 & 41,0 & 42,8 & 47,7 & 33,7 \\
\hline 100 principales empresas & 79.527 & 37.659 & 5.317 & 102.937 & 47,9 & 49,7 & 57,3 & 41,0 \\
\hline 500 principales empresas & 112.040 & 51.348 & 7.498 & 147.254 & 67,5 & 67,8 & 80,8 & 58,7 \\
\hline 1.000 principales empresas & 128.272 & 57.755 & 8.322 & 169.538 & 77,3 & 76,2 & 89,7 & 67,5 \\
\hline Total empresas DIRCE & 166.010 & 75.781 & 9.279 & 251.069 & 100,0 & 100,0 & 100,0 & 100,0 \\
\hline
\end{tabular}

\section{Análisis de la empresa exportadora DIRCE por actividad económica y tramo de exportación}

Como ya se mostraba en el epígrafe anterior, un reducido número de empresas concentra un gran volumen de exportaciones, con especial protagonismo de las grandes empresas de la industria. En este epígrafe se llega a conclusiones similares mediante el estudio de los diferentes tramos de exportación.

Así, en 2017 los 286 exportadores DIRCE, que exportaron más de 100 millones de euros ese año, fueron responsables de más de la mitad de las exportaciones DIRCE $(52,1 \%)$, por importe de 130.863 millones, a pesar de ser realizadas únicamente por el $0,3 \%$ del total de empresas. En perspectiva, en 2017 hubo 14 empresas más que el año anterior que exportaron por encima de ese valor y 88 más que en 2010.

Por el contrario, por número de empresas exportadoras, el grueso se concentró en el tramo inferior, exportaciones por debajo de los 100.000 euros, con 64.495 empresas DIRCE en 2017 que, a pesar de suponer un 68,6\% del total de exportadores, contribuyeron con apenas un $0,3 \%$ al total de las exportaciones (Cuadro 11).

En la evolución reciente, se observa un incremento de la concentración de las exportaciones en los tramos superiores; así, en 2019 los exportadores de más de 10 millones representaron el $82,6 \%$ de las exportaciones, 0,9 puntos porcentuales más que en 2016 y 3,8 más que en 2010.

Las empresas industriales tienen mayor peso en los tramos superiores de exportación que las de comercio. Así, en el Cuadro 11 se observa que en 2017 prácticamente la mitad de las empresas exportadoras DIRCE de la industria (49,5\%) exportó más de 100.000 euros, frente a solo el 32,3\% del comercio. Estas mismas empresas aglutinaron el 99,9\% del valor exportado por la industria y el $99,5 \%$ del comercio.

Además, la industria concentró a más del $70 \%$ de las empresas exportadoras DIRCE de más de 100 millones (208 de las 286), que fueron responsables de más de la mitad de las exportaciones de las empresas industriales DIRCE $(55,8 \%)$ y más de un tercio de las exportaciones de comercio declarado DIRCE $(36,9 \%)$. 
CUADRO 10

NÚMERO DE EMPRESAS EXPORTADORAS DIRCE Y VALOR DE SUS EXPORTACIONES (COMERCIO DECLARADO) POR TRAMOS DE EXPORTACIÓN

\begin{tabular}{|c|c|c|c|c|c|c|c|c|c|c|}
\hline \multirow[b]{2}{*}{$\begin{array}{c}\text { Tramo de exportación } \\
\text { en euros }\end{array}$} & \multicolumn{5}{|c|}{ Número de empresas exportadoras DIRCE } & \multicolumn{5}{|c|}{ Valor de las exportaciones (millones de euros) } \\
\hline & 2010 & 2015 & 2016 & 2017 & $\begin{array}{c}\text { Variación } \\
2017 / 2016(\%)\end{array}$ & 2010 & 2015 & 2016 & 2017 & $\begin{array}{l}\text { Variación } \\
\text { 2017/2016 (\%) }\end{array}$ \\
\hline Menos de 100.000 & 45.392 & 66.054 & 65.989 & 64.495 & $-2,3$ & 702 & 796 & 774 & 773 & $-0,2$ \\
\hline $100.000-249.999$ & 5.569 & 5.889 & 5.886 & 5.737 & $-2,5$ & 916 & 956 & 952 & 926 & $-2,6$ \\
\hline $250.000-499.999$ & 4.833 & 4.800 & 4.600 & 4.427 & $-3,8$ & 1.749 & 1.743 & 1.684 & 1.613 & $-4,2$ \\
\hline $500.000-999.999$ & 4.616 & 5.084 & 4.947 & 4.964 & 0,3 & 3.313 & 3.654 & 3.556 & 3.585 & 0,8 \\
\hline $1.000 .000-9.999 .999$ & 9.326 & 10.933 & 11.098 & 11.236 & 1,2 & 29.815 & 34.925 & 35.975 & 36.694 & 2,0 \\
\hline $10.000 .000-99.999 .999$ & 2.113 & 2.675 & 2.692 & 2.865 & 6,4 & 55.652 & 70.005 & 70.966 & 76.615 & 8,0 \\
\hline Más de 100.000 .000 & 198 & 268 & 272 & 286 & 5,1 & 80.108 & 116.853 & 121.296 & 130.863 & 7,9 \\
\hline Total & 72.047 & 95.703 & 95.484 & 94.010 & $-1,5$ & 172.255 & 228.932 & 235.203 & 251.069 & 6,7 \\
\hline \multirow{2}{*}{$\begin{array}{c}\text { Tramo de exportación } \\
\text { en euros }\end{array}$} & \multicolumn{5}{|c|}{$\begin{array}{l}\text { Porcentaje sobre el total de empresas } \\
\text { exportadoras DIRCE }\end{array}$} & \multicolumn{5}{|c|}{$\begin{array}{l}\text { Porcentaje sobre el total de exportaciones de las } \\
\text { empresas DIRCE }\end{array}$} \\
\hline & 2010 & 2015 & 2016 & 2017 & $\begin{array}{l}\text { Variación } \\
2017 / 2016 \text { (pp) }\end{array}$ & 2010 & 2015 & 2016 & 2017 & $\begin{array}{l}\text { Variación } \\
2017 / 2016 \text { (pp) }\end{array}$ \\
\hline Menos de 100.000 & 63,0 & 69,0 & 69,1 & 68,6 & $-0,5$ & 0,4 & 0,3 & 0,3 & 0,3 & 0,0 \\
\hline $100.000-249.999$ & 7,7 & 6,2 & 6,2 & 6,1 & $-0,1$ & 0,5 & 0,4 & 0,4 & 0,4 & 0,0 \\
\hline $250.000-499.999$ & 6,7 & 5,0 & 4,8 & 4,7 & $-0,1$ & 1,0 & 0,8 & 0,7 & 0,6 & $-0,1$ \\
\hline $500.000-999.999$ & 6,4 & 5,3 & 5,2 & 5,3 & 0,1 & 1,9 & 1,6 & 1,5 & 1,4 & $-0,1$ \\
\hline $1.000 .000-9.999 .999$ & 12,9 & 11,4 & 11,6 & 12,0 & 0,3 & 17,3 & 15,3 & 15,3 & 14,6 & $-0,7$ \\
\hline $10.000 .000-99.999 .999$ & 2,9 & 2,8 & 2,8 & 3,0 & 0,2 & 32,3 & 30,6 & 30,2 & 30,5 & 0,3 \\
\hline Más de 100.000 .000 & 0,3 & 0,3 & 0,3 & 0,3 & 0,0 & 46,5 & 51,0 & 51,6 & 52,1 & 0,6 \\
\hline Total & 100,0 & 100,0 & 100,0 & 100,0 & - & 100,0 & 100,0 & 100,0 & 100,0 & - \\
\hline
\end{tabular}

CUADRO 11

NÚMERO DE EMPRESAS EXPORTADORAS DIRCE Y VALOR DE SUS EXPORTACIONES (COMERCIO DECLARADO) POR TRAMOS Y ACTIVIDAD PRINCIPAL EN 2017

\begin{tabular}{|c|c|c|c|c|c|c|c|c|}
\hline \multirow{2}{*}{$\begin{array}{l}\text { Tramos de exportación } \\
\text { en euros }\end{array}$} & \multicolumn{4}{|c|}{ Número de empresas exportadoras DIRCE } & \multicolumn{4}{|c|}{ Valor de las exportaciones (millones de euros) } \\
\hline & $\begin{array}{l}\text { Industria } \\
\text { (BCDE) }\end{array}$ & $\begin{array}{l}\text { Comercio } \\
\text { (G) }\end{array}$ & $\begin{array}{c}\text { Resto } \\
\text { actividades }\end{array}$ & Total & $\begin{array}{l}\text { Industria } \\
\text { (BCDE) }\end{array}$ & $\begin{array}{l}\text { Comercio } \\
\text { (G) }\end{array}$ & $\begin{array}{c}\text { Resto } \\
\text { actividades }\end{array}$ & Total \\
\hline Menos de 100.000 & 13.331 & 27.848 & 23.316 & 64.495 & 230 & 377 & 166 & 773 \\
\hline $100.000-249.999$ & 1.930 & 2.886 & 921 & 5.737 & 311 & 467 & 148 & 926 \\
\hline $250.000-499.999$ & 1.655 & 2.139 & 633 & 4.427 & 606 & 778 & 230 & 1.613 \\
\hline $500.000-999.999$ & 2.047 & 2.376 & 541 & 4.964 & 1.493 & 1.708 & 384 & 3.585 \\
\hline $1.000 .000-9.999 .999$ & 5.377 & 4.963 & 896 & 11.236 & 18.775 & 15.252 & 2.666 & 36.694 \\
\hline $10.000 .000-99.999 .999$ & 1.875 & 867 & 123 & 2.865 & 51.909 & 21.673 & 3.033 & 76.615 \\
\hline Más de 100.000 .000 & 201 & 76 & 9 & 286 & 92.686 & 35.526 & 2.651 & 130.863 \\
\hline Total & 26.416 & 41.155 & 26.439 & 94.010 & 166.010 & 75.781 & 9.279 & 251.069 \\
\hline \multirow{2}{*}{$\begin{array}{l}\text { Tramos de exportación } \\
\text { en euros }\end{array}$} & \multicolumn{4}{|c|}{$\begin{array}{l}\text { Porcentaje sobre las empresas exportadoras } \\
\text { DIRCE de cada actividad }\end{array}$} & \multicolumn{4}{|c|}{$\begin{array}{l}\text { Porcentaje sobre las exportaciones de } \\
\text { empresas DIRCE de cada actividad }\end{array}$} \\
\hline & $\begin{array}{l}\text { Industria } \\
\text { (BCDE) }\end{array}$ & $\begin{array}{l}\text { Comercio } \\
\text { (G) }\end{array}$ & $\begin{array}{c}\text { Resto } \\
\text { actividades }\end{array}$ & Total & $\begin{array}{l}\text { Industria } \\
\text { (BCDE) }\end{array}$ & $\begin{array}{c}\text { Comercio } \\
\text { (G) }\end{array}$ & \begin{tabular}{|c|} 
Resto \\
actividades
\end{tabular} & Total \\
\hline Menos de 100.000 & 50,5 & 67,7 & 88,2 & 68,6 & 0,1 & 0,5 & 1,8 & 0,3 \\
\hline $100.000-249.999$ & 7,3 & 7,0 & 3,5 & 6,1 & 0,2 & 0,6 & 1,6 & 0,4 \\
\hline $250.000-499.999$ & 6,3 & 5,2 & 2,4 & 4,7 & 0,4 & 1,0 & 2,5 & 0,6 \\
\hline 500.000 - 999.999 & 7,7 & 5,8 & 2,0 & 5,3 & 0,9 & 2,3 & 4,1 & 1,4 \\
\hline $1.000 .000-9.999 .999$ & 20,4 & 12,1 & 3,4 & 12,0 & 11,3 & 20,1 & 28,7 & 14,6 \\
\hline $10.000 .000-99.999 .999$ & 7,1 & 2,1 & 0,5 & 3,0 & 31,3 & 28,6 & 32,7 & 30,5 \\
\hline Más de 100.000 .000 & 0,8 & 0,2 & 0,0 & 0,3 & 55,8 & 46,9 & 28,6 & 52,1 \\
\hline Total & 100,0 & 100,0 & 100,0 & 100,0 & 100,0 & 100,0 & 100,0 & 100,0 \\
\hline
\end{tabular}




\section{Análisis de la empresa exportadora DIRCE por destino geográfico de las exportaciones}

La UE es el destino al que exportan más empresas españolas si se tiene en consideración el comercio total (pero no si se tiene solo en cuenta el comercio declarado) y, dentro de esta área, destacan Francia, Portugal, Alemania e Italia. Entre los destinos extracomunitarios a los que exportan más empresas españolas destacan EE UU, Suiza, China y México. Si se atiende al valor de lo exportado, Francia, dentro de la UE y EE UU, entre los países no comunitarios, figuran como nuestros principales mercados.

En el análisis de los destinos geográficos conviene recordar el distinto tratamiento entre el comercio declarado extracomunitario y el intracomunitario, puesto que en este último no se incluye el comercio bajo umbral que, aun no siendo muy significativo en el valor de las exportaciones, sí lo es en lo que respecta al número de empresas (mayor detalle en el anexo metodológico). Esta característica da lugar a que no tenga sentido realizar comparaciones, a partir de los datos de comercio declarado, entre el número de empresas que exportan a la UE y las que exportan a terceros mercados, y a que las comparaciones sobre el valor de lo exportado a cada una de estas áreas geográficas deban realizarse con cierta cautela.

Así, cuando se toma en consideración el comercio total DIRCE, que sí incluye la estimación del comercio bajo umbral, se observa que en 2017 había más empresas que exportaban a la UE que fuera de ella, 107.713 frente a 85.409 (Cuadro 1.A). Si el análisis se restringe al comercio declarado, los resultados se ven distorsionados al no incluirse las empresas DIRCE que exportaron a la UE y no superaron el umbral de exención Intrastat.
No obstante, el impacto del valor de las exportaciones bajo umbral (a la UE) es limitado. Prueba de ello es que las empresas de comercio declarado DIRCE fueron responsables del $98,5 \%$ de las exportaciones totales realizadas por las empresas DIRCE (Cuadro 1B).

Teniendo en cuenta estas salvedades y en términos de comercio declarado DIRCE, se observa que en 2017 las exportaciones a la UE representaron más de dos tercios del total $(66,8 \%)$ y fueron realizadas por 27.133 empresas (Cuadro 12). De estas empresas, más de dos tercios (18.532) habían exportado al mismo tiempo fuera de la UE. Como se ha señalado, estas cifras excluyen las empresas exportadoras y operaciones que no alcanzan el umbral Intrastat.

Por su parte, el comercio extracomunitario representó en 2017 el 33,2\% del total de las exportaciones y fue realizado por $85.409 \mathrm{em}$ presas en 2017. Dentro de este ámbito, el área geográfica a la que exportaron un mayor número de empresas DIRCE fue la de los países europeos no UE, el $43,4 \%$ del total extra-UE, seguida por Asia (excepto Oriente Medio y Próximo), América del Norte y América del Sur, respectivamente, con el $30,5 \%$, $28,2 \%$ y $25,9 \%$ del total extra-UE. Entre 2010 y 2017 destaca el incremento del número de empresas DIRCE que exportaron a América del Norte y a Asia (excepto Oriente Medio y Próximo), y también en el peso sobre el valor de las exportaciones extra-UE, pero en orden invertido.

En términos de valor, el comercio extracomunitario de las empresas DIRCE se concentró, por este orden, en Asia (excepto Oriente Medio y Próximo), países europeos no UE, América del Norte y Norte de África, respectivamente, con un peso sobre el total extra-UE de $18,1 \%, 16,9 \%, 15,3 \%$ y $12,8 \%$. 
CUADRO 12

NÚMERO DE EMPRESAS EXPORTADORAS DIRCE Y VALOR DE SUS EXPORTACIONES (COMERCIO DECLARADO) POR ÁREA GEOGRÁFICA

\begin{tabular}{|c|c|c|c|c|c|c|c|c|c|c|}
\hline \multirow[b]{2}{*}{ Área geográfica } & \multicolumn{5}{|c|}{ Número de empresas exportadoras DIRCE } & \multicolumn{5}{|c|}{ Valor de las exportaciones (millones de euros) } \\
\hline & 2010 & 2015 & 2016 & 2017 & $\begin{array}{l}\text { Variación } \\
2017 / 2016 \\
(\%)\end{array}$ & 2010 & 2015 & 2016 & 2017 & $\begin{array}{c}\text { Variación } \\
\text { 2017/2016 } \\
(\%)\end{array}$ \\
\hline UE & 26.142 & 27.620 & 27.272 & 27.133 & $-0,5$ & 116.524 & 150.028 & 158.557 & 167.768 & 5,8 \\
\hline Extra-UE & 62.880 & 86.979 & 86.961 & 85.409 & $-1,8$ & 55.731 & 78.904 & 76.645 & 83.301 & 8,7 \\
\hline Países europeos no UE & 29.256 & 35.706 & 36.490 & 37.077 & 1,6 & 12.155 & 12.966 & 13.049 & 14.052 & 7,7 \\
\hline Norte de África & 15.945 & 17.363 & 16.807 & 16.684 & $-0,7$ & 6.768 & 10.028 & 10.452 & 10.632 & 1,7 \\
\hline Otros países africanos & 10.264 & 15.914 & 15.246 & 15.115 & $-0,9$ & 2.658 & 3.716 & 3.408 & 3.632 & 6,6 \\
\hline América del Norte & 12.295 & 24.776 & 25.559 & 24.076 & $-5,8$ & 7.110 & 11.279 & 11.248 & 12.715 & 13,0 \\
\hline América Central y Caribe & 12.036 & 18.629 & 19.265 & 19.319 & 0,3 & 4.309 & 6.734 & 6.308 & 6.947 & 10,1 \\
\hline América del Sur & 14.408 & 21.822 & 21.519 & 22.152 & 2,9 & 5.430 & 7.459 & 6.469 & 7.447 & 15,1 \\
\hline Oriente Próximo y $\mathrm{O}$. Medio & 10.353 & 15.614 & 15.185 & 15.005 & $-1,2$ & 4.464 & 8.376 & 7.931 & 7.789 & $-1,8$ \\
\hline Otros países asiáticos & 14.371 & 24.897 & 25.378 & 26.042 & 2,6 & 8.300 & 13.487 & 13.837 & 15.062 & 8,9 \\
\hline Oceanía y regiones polares & 4.080 & 6.570 & 6.853 & 7.241 & 5,7 & 1.170 & 1.388 & 1.214 & 1.572 & 29,4 \\
\hline País no UE indeterminado & 977 & 1.134 & 1.091 & 1.091 & 0,0 & 3.368 & 3.472 & 2.727 & 3.453 & 26,6 \\
\hline Total mundial & 72.047 & 95.703 & 95.484 & 94.010 & $-1,5$ & 172.255 & 228.932 & 235.203 & 251.069 & 6,7 \\
\hline \multirow[b]{2}{*}{ Área geográfica } & \multicolumn{5}{|c|}{$\begin{array}{l}\text { Porcentaje sobre el total de empresas } \\
\text { exportadoras DIRCE }\end{array}$} & \multicolumn{5}{|c|}{$\begin{array}{c}\text { Porcentaje sobre el total de exportaciones de } \\
\text { empresas DIRCE }\end{array}$} \\
\hline & 2010 & 2015 & 2016 & 2017 & $\begin{array}{c}\text { Variación } \\
2017 / 2016 \\
\text { (pp) }\end{array}$ & 2010 & 2015 & 2016 & 2017 & $\begin{array}{c}\text { Variación } \\
2017 / 2016 \\
\text { (pp) }\end{array}$ \\
\hline UE & 36,3 & 28,9 & 28,6 & 28,9 & 0,3 & 67,6 & 65,5 & 67,4 & 66,8 & $-0,6$ \\
\hline Extra-UE & 87,3 & 90,9 & 91,1 & 90,9 & $-0,2$ & 32,4 & 34,5 & 32,6 & 33,2 & 0,6 \\
\hline Extra-UE & \multicolumn{5}{|c|}{$\begin{array}{l}\text { Porcentaje sobre el total de empresas } \\
\text { exportadoras DIRCE extra-UE }\end{array}$} & \multicolumn{5}{|c|}{$\begin{array}{l}\text { Porcentaje sobre el total de exportaciones de } \\
\text { empresas DIRCE extra-UE }\end{array}$} \\
\hline Países europeos no UE & 46,5 & 41,1 & 42,0 & 43,4 & 1,4 & 21,8 & 16,4 & 17,0 & 16,9 & $-0,2$ \\
\hline Norte de África & 25,4 & 20,0 & 19,3 & 19,5 & 0,2 & 12,1 & 12,7 & 13,6 & 12,8 & $-0,9$ \\
\hline Otros países africanos & 16,3 & 18,3 & 17,5 & 17,7 & 0,2 & 4,8 & 4,7 & 4,4 & 4,4 & $-0,1$ \\
\hline América del Norte & 19,6 & 28,5 & 29,4 & 28,2 & $-1,2$ & 12,8 & 14,3 & 14,7 & 15,3 & 0,6 \\
\hline América Central y Caribe & 19,1 & 21,4 & 22,2 & 22,6 & 0,5 & 7,7 & 8,5 & 8,2 & 8,3 & 0,1 \\
\hline América del Sur & 22,9 & 25,1 & 24,7 & 25,9 & 1,2 & 9,7 & 9,5 & 8,4 & 8,9 & 0,5 \\
\hline Oriente Próximo y O. Medio & 16,5 & 18,0 & 17,5 & 17,6 & 0,1 & 8,0 & 10,6 & 10,3 & 9,4 & $-1,0$ \\
\hline Otros países asiáticos & 22,9 & 28,6 & 29,2 & 30,5 & 1,3 & 14,9 & 17,1 & 18,1 & 18,1 & 0,0 \\
\hline Oceanía y regiones polares & 6,5 & 7,6 & 7,9 & 8,5 & 0,6 & 2,1 & 1,8 & 1,6 & 1,9 & 0,3 \\
\hline País no UE indeterminado & 1,6 & 1,3 & 1,3 & 1,3 & 0,0 & 6,0 & 4,4 & 3,6 & 4,1 & 0,6 \\
\hline
\end{tabular}

En el Cuadro 13 se muestran las exportaciones de comercio declarado de empresas DIRCE por países, separando, por un lado, a los países de la UE y, por otro, a una selección de países extra-UE. Dentro de la UE, el $61,9 \%$ de las empresas DIRCE (comercio declarado) que exportaron a esa zona de intercambio tuvo entre sus destinos a Francia, le siguió Portugal, con el $56,8 \%$, y Alemania e Italia, con valores muy similares $(46,9 \%$ y $46,8 \%$, respectivamente). Con respecto al valor exportado a la UE por empresas DIRCE, Francia $\square$ 
volvió a dominar con el $23,0 \%$ del total, seguida por Alemania (17,5\%), Italia (11,9\%), Portugal $(11,1 \%)$ y Reino Unido $(10,6 \%)$.

Con respecto al comercio declarado extracomunitario realizado por empresas DIRCE, el destino al que exportó un mayor número de empresas fue Estados Unidos, con $22.459 \mathrm{em}$ presas en 2017 , el $26,3 \%$ de las empresas
DIRCE que exportaron fuera de la UE. Le siguieron Suiza $(18,2 \%)$, China $(15,3 \%)$, Marruecos $(14,6 \%)$ y México $(14,1 \%)$. En cuanto al valor exportado, el primer destino extracomunitario fue nuevamente Estados Unidos, con el $13,6 \%$ de las exportaciones fuera de la UE, seguido por Marruecos $(7,3 \%)$, Turquía (6,1\%) y China $(6,0 \%)$.

CUADRO 13

NÚMERO DE EMPRESAS EXPORTADORAS DIRCE POR PAÍSES Y ZONAS (UE / EXTRA-UE) Y VALOR DE SUS EXPORTACIONES (ORDENADO DE MÁS A MENOS EXPORTACIONES EN 2017)

\begin{tabular}{|c|c|c|c|c|c|c|c|c|c|}
\hline \multicolumn{10}{|c|}{ Países de la Unión Europea } \\
\hline \multirow{2}{*}{$\begin{array}{l}\text { País } \\
\text { UE }\end{array}$} & \multicolumn{4}{|c|}{$\begin{array}{c}\text { Número de empresas exportadoras } \\
\text { DIRCE }\end{array}$} & \multicolumn{4}{|c|}{$\begin{array}{l}\text { Valor de las exportaciones } \\
\text { (Millones de euros) }\end{array}$} & \multirow{2}{*}{$\begin{array}{c}2017 \\
\text { Exportación } \\
\text { media por } \\
\text { empresa } \\
\text { (Miles de euros) }\end{array}$} \\
\hline & 2016 & 2017 & $\begin{array}{c}\text { Variación } \\
2017 / 2016 \\
(\%)\end{array}$ & $\begin{array}{l}2017 \% \text { s. } \\
\text { total UE }\end{array}$ & 2016 & 2017 & $\begin{array}{c}\text { Variación } \\
2017 / 2016 \\
(\%)\end{array}$ & $\begin{array}{l}2017 \% \text { s. } \\
\text { total UE }\end{array}$ & \\
\hline Francia & 16.945 & 16.788 & $-0,9$ & 61,9 & 36.954 & 38.546 & 4,3 & 23,0 & $2.296,1$ \\
\hline Alemania & 12.690 & 12.715 & 0,2 & 46,9 & 28.097 & 29.289 & 4,2 & 17,5 & $2.303,5$ \\
\hline Italia & 12.684 & 12.691 & 0,1 & 46,8 & 18.200 & 19.964 & 9,7 & 11,9 & $1.573,1$ \\
\hline Portugal & 15.541 & 15.425 & $-0,7$ & 56,8 & 16.649 & 18.606 & 11,8 & 11,1 & $1.206,2$ \\
\hline Reino Unido & 11.100 & 10.927 & $-1,6$ & 40,3 & 18.816 & 17.757 & $-5,6$ & 10,6 & $1.625,1$ \\
\hline Países Bajos & 9.040 & 9.228 & 2,1 & 34,0 & 7.381 & 8.635 & 17,0 & 5,1 & 935,7 \\
\hline Bélgica & 8.405 & 8.469 & 0,8 & 31,2 & 7.589 & 7.716 & 1,7 & 4,6 & 911,1 \\
\hline Polonia & 7.036 & 7.167 & 1,9 & 26,4 & 4.584 & 5.180 & 13,0 & 3,1 & 722,7 \\
\hline República Checa & 5.166 & 5.286 & 2,3 & 19,5 & 2.075 & 2.264 & 9,1 & 1,3 & 428,4 \\
\hline Austria & 4.523 & 4.586 & 1,4 & 16,9 & 2.138 & 2.180 & 2,0 & 1,3 & 475,3 \\
\hline Suecia & 4.492 & 4.511 & 0,4 & 16,6 & 2.049 & 2.082 & 1,6 & 1,2 & 461,5 \\
\hline Grecia & 4.638 & 4.681 & 0,9 & 17,3 & 1.470 & 1.949 & 32,6 & 1,2 & 416,3 \\
\hline Rumanía & 4.401 & 4.642 & 5,5 & 17,1 & 1.614 & 1.819 & 12,7 & 1,1 & 391,9 \\
\hline Dinamarca & 4.384 & 4.419 & 0,8 & 16,3 & 1.384 & 1.534 & 10,8 & 0,9 & 347,2 \\
\hline Hungría & 3.584 & 3.684 & 2,8 & 13,6 & 1.348 & 1.532 & 13,7 & 0,9 & 415,8 \\
\hline Irlanda & 3.619 & 3.703 & 2,3 & 13,6 & 1.740 & 1.196 & $-31,3$ & 0,7 & 323,0 \\
\hline Eslovaquia & 2.667 & 2.785 & 4,4 & 10,3 & 855 & 950 & 11,1 & 0,6 & 341,0 \\
\hline Finlandia & 3.182 & 3.273 & 2,9 & 12,1 & 899 & 817 & $-9,1$ & 0,5 & 249,5 \\
\hline Eslovenia & 2.341 & 2.459 & 5,0 & 9,1 & 454 & 556 & 22,5 & 0,3 & 226,1 \\
\hline Bulgaria & 3.108 & 3.256 & 4,8 & 12,0 & 453 & 532 & 17,5 & 0,3 & 163,5 \\
\hline Croacia & 1.867 & 1.974 & 5,7 & 7,3 & 361 & 413 & 14,4 & 0,2 & 209,2 \\
\hline Lituania & 2.645 & 2.709 & 2,4 & 10,0 & 351 & 384 & 9,3 & 0,2 & 141,7 \\
\hline Malta & 2.053 & 2.122 & 3,4 & 7,8 & 230 & 334 & 45,2 & 0,2 & 157,3 \\
\hline Luxemburgo & 1.558 & 1.652 & 6,0 & 6,1 & 244 & 273 & 12,0 & 0,2 & 165,4 \\
\hline Chipre & 2.020 & 2.054 & 1,7 & 7,6 & 227 & 252 & 11,1 & 0,2 & 122,9 \\
\hline Estonia & 1.963 & 2.088 & 6,4 & 7,7 & 203 & 226 & 11,1 & 0,1 & 108,3 \\
\hline Letonia & 1.956 & 2.021 & 3,3 & 7,4 & 186 & 197 & 5,8 & 0,1 & 97,4 \\
\hline País UE inderterminado & 1.185 & 1.391 & 17,4 & 5,1 & 2.007 & 2.585 & 28,8 & 1,5 & $1.858,7$ \\
\hline Total UE & 27.272 & 27.133 & $-0,5$ & 100,0 & 158.557 & 167.768 & 5,8 & 100,0 & $6.183,2$ \\
\hline
\end{tabular}


CUADRO 13

NÚMERO DE EMPRESAS EXPORTADORAS DIRCE POR PAÍSES Y ZONAS (UE / EXTRA-UE) Y VALOR DE SUS EXPORTACIONES (ORDENADO DE MÁS A MENOS EXPORTACIONES EN 2017) (continuación)

\begin{tabular}{|c|c|c|c|c|c|c|c|c|c|}
\hline \multicolumn{10}{|c|}{ Selección de países extra-UE } \\
\hline \multirow{2}{*}{$\begin{array}{c}\text { País } \\
\text { Extra-UE }\end{array}$} & \multicolumn{4}{|c|}{$\begin{array}{c}\text { Número de empresas exportadoras } \\
\text { DIRCE }\end{array}$} & \multicolumn{4}{|c|}{$\begin{array}{l}\text { Valor de las exportaciones } \\
\text { (Millones de euros) }\end{array}$} & \multirow{2}{*}{$\begin{array}{l}2017 \text { Exportación } \\
\text { media por } \\
\text { empresa (miles } \\
\text { de euros) }\end{array}$} \\
\hline & 2016 & 2017 & $\begin{array}{c}\text { Variación } \\
2017 / 2016 \\
(\%)\end{array}$ & $\begin{array}{l}2017 \% \text { s. } \\
\text { total UE }\end{array}$ & 2016 & 2017 & $\begin{array}{c}\text { Variación } \\
2017 / 2016 \\
(\%)\end{array}$ & $\begin{array}{l}2017 \% \text { s. } \\
\text { total UE }\end{array}$ & \\
\hline Estados Unidos & 24.040 & 22.459 & $-6,6$ & 26,3 & 10.082 & 11.342 & 12,5 & 13,6 & 505,0 \\
\hline Marruecos & 12.292 & 12.489 & 1,6 & 14,6 & 5.445 & 6.075 & 11,6 & 7,3 & 486,4 \\
\hline Turquía & 7.142 & 7.162 & 0,3 & 8,4 & 4.703 & 5.070 & 7,8 & 6,1 & 707,9 \\
\hline China & 12.713 & 13.048 & 2,6 & 15,3 & 4.100 & 4.963 & 21,1 & 6,0 & 380,4 \\
\hline México & 11.837 & 12.042 & 1,7 & 14,1 & 3.833 & 4.299 & 12,1 & 5,2 & 357,0 \\
\hline Suiza & 15.225 & 15.544 & 2,1 & 18,2 & 3.623 & 3.652 & 0,8 & 4,4 & 235,0 \\
\hline Argelia & 4.589 & 4.272 & $-6,9$ & 5,0 & 2.704 & 2.400 & $-11,2$ & 2,9 & 561,8 \\
\hline Japón & 6.443 & 6.652 & 3,2 & 7,8 & 2.195 & 2.212 & 0,8 & 2,7 & 332,5 \\
\hline Brasil & 5.247 & 5.369 & 2,3 & 6,3 & 1.998 & 2.158 & 8,0 & 2,6 & 401,9 \\
\hline Arabia Saudí & 4.401 & 4.342 & $-1,3$ & 5,1 & 2.241 & 2.117 & $-5,5$ & 2,5 & 487,6 \\
\hline Federación de Rusia & 4.311 & 4.532 & 5,1 & 5,3 & 1.500 & 1.770 & 18,0 & 2,1 & 390,5 \\
\hline República de Corea & 4.742 & 4.830 & 1,9 & 5,7 & 1.530 & 1.598 & 4,5 & 1,9 & 330,9 \\
\hline Emiratos Árabes Unidos & 7.055 & 6.685 & $-5,2$ & 7,8 & 1.601 & 1.458 & $-8,9$ & 1,8 & 218,1 \\
\hline Canadá & 6.532 & 6.903 & 5,7 & 8,1 & 1.158 & 1.373 & 18,6 & 1,6 & 198,9 \\
\hline Israel & 5.453 & 5.584 & 2,4 & 6,5 & 1.337 & 1.358 & 1,6 & 1,6 & 243,1 \\
\hline Australia & 5.815 & 6.165 & 6,0 & 7,2 & 1.026 & 1.305 & 27,2 & 1,6 & 211,7 \\
\hline Chile & 7.834 & 8.011 & 2,3 & 9,4 & 1.325 & 1.289 & $-2,7$ & 1,5 & 160,9 \\
\hline Argentina & 4.688 & 5.319 & 13,5 & 6,2 & 769 & 1.202 & 56,4 & 1,4 & 226,1 \\
\hline India & 5.731 & 5.925 & 3,4 & 6,9 & 1.179 & 1.178 & $-0,1$ & 1,4 & 198,8 \\
\hline Sudáfrica & 3.877 & 4.134 & 6,6 & 4,8 & 1.020 & 1.079 & 5,8 & 1,3 & 261,0 \\
\hline Egipto & 3.307 & 3.132 & $-5,3$ & 3,7 & 1.280 & 1.061 & $-17,1$ & 1,3 & 338,9 \\
\hline Noruega & 5.730 & 6.031 & 5,3 & 7,1 & 885 & 956 & 8,1 & 1,1 & 158,5 \\
\hline Hong Kong & 6.490 & 6.409 & $-1,2$ & 7,5 & 902 & 921 & 2,1 & 1,1 & 143,7 \\
\hline Túnez & 3.515 & 3.545 & 0,9 & 4,2 & 709 & 769 & 8,5 & 0,9 & 216,8 \\
\hline Malasia & 2.383 & 2.441 & 2,4 & 2,9 & 569 & 638 & 12,1 & 0,8 & 261,4 \\
\hline Tailandia & 2.628 & 2.850 & 8,4 & 3,3 & 529 & 582 & 10,1 & 0,7 & 204,4 \\
\hline Singapur & 3.827 & 3.946 & 3,1 & 4,6 & 499 & 519 & 4,0 & 0,6 & 131,4 \\
\hline Taiwán & 3.882 & 3.916 & 0,9 & 4,6 & 437 & 463 & 5,8 & 0,6 & 118,2 \\
\hline Indonesia & 1.737 & 1.844 & 6,2 & 2,2 & 369 & 427 & 15,7 & 0,5 & 231,7 \\
\hline Vietnam & 2.204 & 2.408 & 9,3 & 2,8 & 357 & 392 & 9,8 & 0,5 & 163,0 \\
\hline Qatar & 2.300 & 2.408 & 4,7 & 2,8 & 323 & 392 & 21,3 & 0,5 & 162,9 \\
\hline Rep. Islámica de Irán & 1.859 & 1.866 & 0,4 & 2,2 & 339 & 388 & 14,4 & 0,5 & 208,0 \\
\hline Ucrania & 2.361 & 2.588 & 9,6 & 3,0 & 246 & 314 & 27,3 & 0,4 & 121,1 \\
\hline Nigeria & 1.990 & 1.896 & $-4,7$ & 2,2 & 207 & 208 & 0,5 & 0,2 & 109,6 \\
\hline Kazajstán & 954 & 1.000 & 4,8 & 1,2 & 238 & 159 & $-33,1$ & 0,2 & 159,1 \\
\hline Islandia & 1.087 & 1.135 & 4,4 & 1,3 & 166 & 50 & $-69,6$ & 0,1 & 44,4 \\
\hline Total extra-UE & 86.961 & 85.409 & $-1,8$ & 100,0 & 76.645 & 83.301 & 8,7 & 100,0 & 975,3 \\
\hline Total mundial & 95.484 & 94.010 & $-1,5$ & - & 235.203 & 251.069 & 6,7 & - & $2.670,7$ \\
\hline
\end{tabular}


Con respecto a la exportación media por empresa, el análisis se realiza de nuevo de forma independiente para las dos zonas de intercambio (UE y extra-UE), ya que los datos no son comparables por comprender únicamente el comercio declarado.

Así, las empresas DIRCE de comercio declarado que exportaron a la UE tuvieron una exportación intracomunitaria media de 6,2 millones de euros (dato muy influenciado por el umbral de exención de 400.000 euros en 2017). Los destinos que mostraron un mayor valor medio de exportación por empresa y país fueron Alemania y Francia, ambos con una cifra próxima a los 2,3 millones de euros. Les siguió Reino Unido (1,63 millones), Italia (1,57 millones) y Portugal (1,21 millones).

Con respecto a las empresas DIRCE que realizaron exportaciones extracomunitarias, las exportaciones medias a ese área fueron de 975,3 miles de euros y los destinos con mayor valor medio de exportación por empresa y país fueron Turquía, con una exportación media de 707.900 euros, seguido por Argelia (561.800 euros), Estados Unidos (505.000 euros), Arabia Saudí (487.600 euros) y Marruecos (486.400 euros).

\section{Número de empresas exportadoras DIRCE por número de destinos}

Aunque la mayor parte de las empresas DIRCE exportan a un solo país de destino, las empresas que exportan a múltiples destinos son las que contribuyen en mayor medida al valor total de las exportaciones.

En 2017 aproximadamente la mitad de las empresas exportadoras DIRCE de comercio declarado exportaron a un único país, si bien en términos del valor de las exportaciones apenas representaron el 2,3\% del total. En el extremo opuesto, las 5.933 empresas que exportaron en 2017 a veinte o más destinos (el $6,3 \%$ del total) fueron responsables del 68,5\% de las exportaciones (Cuadro 14).

\section{Características de la empresa exportadora con datos de Eurostat}

Los datos de Eurostat para España difieren, por cuestiones metodológicas, de los que se han analizado en los epígrafes anteriores con datos de Aduanas, ya que Eurostat cruza los operadores de comercio total (no únicamente del comercio declarado) con el directorio de empresas de cada país. Así, para 2017, con los datos de Eurostat, el número de empresas españolas que cruzaban con el directorio ascendía a $149.060^{4}$ (frente a las 94.010 empresas DIRCE calculadas por Aduanas con comercio declarado) y realizaron exportaciones por $255.952 \mathrm{mi}-$ llones (frente a los 251.069 calculados por Aduanas). En la comparación de estos datos se observa que si bien la diferencia del valor exportado es poco significativa (inferior al $2 \%$ ), la del número de empresas sí es muy destacable, puesto que Eurostat toma en consideración 55.050 empresas del comercio intracomunitario bajo umbral que cruzaban con el DIRCE que Aduanas no analiza en su estudio del comercio exterior por características de la empresa.

La comparación de España frente a los países de la UE por tamaño de empresas exportadoras (Cuadros 15A y 15B) muestra una mayor presencia de las pymes exportadoras en España, derivada del mayor peso de las microempresas. Además, las pymes españolas $\square$

4 La cifra de 2017 coincide exactamente con la que Aduanas ofrece para España de comercio total DIRCE en el Cuadro $1 \mathrm{~A}$ y es muy similar a la de años anteriores. 
CUADRO 14 NÚMERO DE EMPRESAS EXPORTADORAS DIRCE Y VALOR DE SUS EXPORTACIONES (COMERCIO DECLARADO) POR NÚMERO DE PAÍSES CONTRAPARTIDA

\begin{tabular}{|c|c|c|c|c|c|c|c|c|c|c|}
\hline \multirow{2}{*}{$\begin{array}{l}\mathrm{N} .^{\circ} \text { de } \\
\text { países }\end{array}$} & \multicolumn{5}{|c|}{ Número de empresas exportadoras DIRCE } & \multicolumn{5}{|c|}{ Valor de las exportaciones (millones de euros) } \\
\hline & 2010 & 2015 & 2016 & 2017 & $\begin{array}{c}\text { Variación } \\
\text { 2017/2016 (\%) }\end{array}$ & 2010 & 2015 & 2016 & 2017 & $\begin{array}{c}\text { Variación } \\
\text { 2017/2016 (\%) }\end{array}$ \\
\hline 1 & 37.656 & 49.928 & 49.605 & 47.705 & $-3,8$ & 5.698 & 5.525 & 5.583 & 5.867 & 5,1 \\
\hline 2 & 9.659 & 12.977 & 12.712 & 12.844 & 1,0 & 4.559 & 4.318 & 4.006 & 4.053 & 1,2 \\
\hline $3-5$ & 10.410 & 13.628 & 13.874 & 13.801 & $-0,5$ & 11.343 & 11.038 & 11.056 & 11.964 & 8,2 \\
\hline $6-9$ & 5.275 & 7.011 & 6.969 & 7.076 & 1,5 & 13.185 & 14.416 & 13.716 & 17.171 & 25,2 \\
\hline $10-14$ & 3.242 & 4.101 & 4.132 & 4.201 & 1,7 & 18.658 & 15.555 & 18.647 & 17.867 & $-4,2$ \\
\hline $15-19$ & 1.874 & 2.365 & 2.496 & 2.450 & $-1,8$ & 13.392 & 20.088 & 17.859 & 22.143 & 24,0 \\
\hline 20 o más & 3.931 & 5.693 & 5.696 & 5.933 & 4,2 & 105.419 & 157.992 & 164.335 & 172.004 & 4,7 \\
\hline Total & 72.047 & 95.703 & 95.484 & 94.010 & $-1,5$ & 172.255 & 228.932 & 235.203 & 251.069 & 6,7 \\
\hline \multicolumn{11}{|c|}{ Porcentaje sobre el total de la columna } \\
\hline $\begin{array}{l}\mathrm{N} .^{\circ} \text { de } \\
\text { países }\end{array}$ & 2010 & 2015 & 2016 & 2017 & $\begin{array}{c}\text { Variación } \\
\text { 2017/2016 } \\
\text { (pp) }\end{array}$ & 2010 & 2015 & 2016 & 2017 & $\begin{array}{c}\text { Variación } \\
\text { 2017/2016 } \\
\text { (pp) }\end{array}$ \\
\hline 1 & 52,3 & 52,2 & 52,0 & 50,7 & $-1,2$ & 3,3 & 2,4 & 2,4 & 2,3 & 0,0 \\
\hline 2 & 13,4 & 13,6 & 13,3 & 13,7 & 0,3 & 2,6 & 1,9 & 1,7 & 1,6 & $-0,1$ \\
\hline $3-5$ & 14,4 & 14,2 & 14,5 & 14,7 & 0,2 & 6,6 & 4,8 & 4,7 & 4,8 & 0,1 \\
\hline $6-9$ & 7,3 & 7,3 & 7,3 & 7,5 & 0,2 & 7,7 & 6,3 & 5,8 & 6,8 & 1,0 \\
\hline $10-14$ & 4,5 & 4,3 & 4,3 & 4,5 & 0,1 & 10,8 & 6,8 & 7,9 & 7,1 & $-0,8$ \\
\hline $15-19$ & 2,6 & 2,5 & 2,6 & 2,6 & 0,0 & 7,8 & 8,8 & 7,6 & 8,8 & 1,2 \\
\hline 20 o más & 5,5 & 5,9 & 6,0 & 6,3 & 0,3 & 61,2 & 69,0 & 69,9 & 68,5 & $-1,4$ \\
\hline Total & 100,0 & 100,0 & 100,0 & 100,0 & - & 100,0 & 100,0 & 100,0 & 100,0 & - \\
\hline
\end{tabular}

también contribuyen al valor exportado con un porcentaje superior a la media de la UE y a la mayor parte de los países analizados. Por otro lado, el valor medio exportado por las empresas españolas es inferior al promedio de la UE en todos los tramos de tamaño.

Los datos analizados permiten también explorar la relevancia de determinados factores que inciden en la probabilidad y capacidad de exportar. Así, los datos relativos a la propiedad de las empresas (Cuadro 16) confirman la importancia de la contribución al valor de la exportación de las empresas que cuentan con participación de capital extranjero o disponen de filiales en el exterior. Igualmente, se constata que la propensión a exportar de las empresas españolas aumenta con su tamaño y que es más elevada en el sector industrial y, dentro de este, en las manufacturas (Cuadros 17 y 18). Además, la mayor parte de las empresas que exportan realizan, a su vez, importaciones y son las empresas exportadoras-importadoras las que en mayor medida contribuyen al valor total de lo exportado (Cuadro 19).

Así, por lo que se refiere al tamaño de las empresas exportadoras, en España, en el año 2017 , el $98,3 \%$ de las empresas exportadoras del directorio eran pymes, cifra superior a la del conjunto de la UE $(97,9 \%)$, así como a la de Alemania, Francia y Reino Unido, aunque inferior a la de Italia. Ello es debido al mayor peso relativo que las microempresas presentaban en España, 70,2\%, frente al 67,4\% en la UE, y, dentro de los diez principales exportadores, $D$ 
solo por debajo del valor de Países Bajos y PoIonia. En cambio, tanto en las pequeñas como en las medianas empresas, la proporción era menor en España que para la UE. Lo mismo ocurría para las grandes empresas, que suponían tan solo un 1,7\% de las empresas exportadoras del directorio, por debajo del 2,1\% de la UE. Solo en Italia y Países Bajos este porcentaje era menor.

Con respecto al valor de las exportaciones, en 2017, en el conjunto de la UE, las grandes empresas (250 o más asalariados) contribuyeron con el $60,8 \%$ al total de exportaciones de empresas del directorio. Este dato está muy influenciado por la cifra de Alemania, el primer exportador de la UE, donde las grandes empresas aglutinaban el $77,0 \%$ de las exportaciones de empresas del directorio (Cuadro 15B). En España el valor se situaba en el $48,9 \%$ del total, siendo solo inferior, entre los diez primeros exportadores, al de Países Bajos, Bélgica e Italia. Por el contrario, en España más de la mitad de las exportaciones en 2017 $(51,1 \%)$ la realizaron las pymes.

CUADRO 15A

NÚMERO DE EMPRESAS EXPORTADORAS POR ESTRATO DE ASALARIADOS EN 2017 (10 PRINCIPALES EXPORTADORES DE LA UE)

\begin{tabular}{|c|c|c|c|c|c|c|c|}
\hline \multirow[b]{2}{*}{ País/estrato } & \multicolumn{6}{|c|}{ Número de empresas exportadoras del directorio de empresas* } & \multirow[b]{2}{*}{$\begin{array}{c}\text { Total } \\
\text { exportadores } \\
\text { (operadores) }\end{array}$} \\
\hline & $\begin{array}{c}0 \text { a } 9 \\
\text { asalariados } \\
\text { micro }\end{array}$ & $\begin{array}{c}10 \text { a } 49 \\
\text { asalariados } \\
\text { pequeña }\end{array}$ & $\begin{array}{c}50 \text { a } 249 \\
\text { asalariados } \\
\text { mediana }\end{array}$ & $\begin{array}{c}\text { Pyme } \\
\text { (0 a } 249 \\
\text { asalariados) }\end{array}$ & $\begin{array}{c}>=250 \\
\text { asalariados } \\
\text { grande }\end{array}$ & $\begin{array}{c}\text { Total } \\
\text { empresas } \\
\text { directorio }\end{array}$ & \\
\hline Alemania & 172.648 & 58.196 & 22.228 & 253.072 & 6.956 & 260.028 & 296.508 \\
\hline Países Bajos & 84.283 & 16.179 & 5.075 & 105.537 & 1.272 & 106.809 & 115.706 \\
\hline Francia & 65.649 & 20.470 & 7.577 & 93.696 & 2.910 & 96.606 & 107.289 \\
\hline Italia & 129.833 & 55.001 & 10.838 & 195.672 & 2.011 & 197.683 & 222.315 \\
\hline Reino Unido & 69.818 & 30.405 & 10.381 & 110.604 & 3.518 & 114.122 & 118.098 \\
\hline Bélgica & 30.515 & 11.334 & 2.801 & 44.650 & 792 & 45.442 & 81.480 \\
\hline España & 104.624 & 32.802 & 9.119 & 146.545 & 2.515 & 149.060 & 165.623 \\
\hline Polonia & 89.109 & 25.726 & 8.959 & 123.794 & 2.545 & 126.339 & 127.160 \\
\hline Rep. Checa & 6.422 & 5.717 & 3.678 & 15.817 & 1.218 & 17.035 & 18.386 \\
\hline Austria & 29.133 & 9.858 & 2.914 & 41.905 & 959 & 42.864 & 43.766 \\
\hline Total UE & 1.009 .269 & 346.039 & 109.492 & 1.464 .800 & 31.556 & 1.496 .356 & 1.658 .145 \\
\hline \multirow[b]{2}{*}{ País/estrato } & \multicolumn{6}{|c|}{ Porcentaje sobre el total de empresas exportadoras del directorio de empresas* } & \multirow{2}{*}{$\begin{array}{c}\% \\
\text { exportadores } \\
\text { directorio } \\
\text { s. total } \\
\text { exportadores }\end{array}$} \\
\hline & $\begin{array}{c}0 \text { a } 9 \\
\text { asalariados } \\
\text { micro }\end{array}$ & $\begin{array}{c}10 \text { a } 49 \\
\text { asalariados } \\
\text { pequeña }\end{array}$ & $\begin{array}{c}50 \text { a } 249 \\
\text { asalariados } \\
\text { mediana }\end{array}$ & $\begin{array}{c}\text { Pyme } \\
\text { (0 a } 249 \\
\text { asalariados) }\end{array}$ & $\begin{array}{c}>=250 \\
\text { asalariados } \\
\text { grande }\end{array}$ & $\begin{array}{c}\text { Total } \\
\text { empresas } \\
\text { directorio }\end{array}$ & \\
\hline Alemania & 66,4 & 22,4 & 8,5 & 97,3 & 2,7 & 100,0 & 87,7 \\
\hline Países Bajos & 78,9 & 15,1 & 4,8 & 98,8 & 1,2 & 100,0 & 92,3 \\
\hline Francia & 68,0 & 21,2 & 7,8 & 97,0 & 3,0 & 100,0 & 90,0 \\
\hline Italia & 65,7 & 27,8 & 5,5 & 99,0 & 1,0 & 100,0 & 88,9 \\
\hline Reino Unido & 61,2 & 26,6 & 9,1 & 96,9 & 3,1 & 100,0 & 96,6 \\
\hline Bélgica & 67,2 & 24,9 & 6,2 & 98,3 & 1,7 & 100,0 & 55,8 \\
\hline España & 70,2 & 22,0 & 6,1 & 98,3 & 1,7 & 100,0 & 90,0 \\
\hline Polonia & 70,5 & 20,4 & 7,1 & 98,0 & 2,0 & 100,0 & 99,4 \\
\hline Rep. Checa & 37,7 & 33,6 & 21,6 & 92,9 & 7,1 & 100,0 & 92,7 \\
\hline Austria & 68,0 & 23,0 & 6,8 & 97,8 & 2,2 & 100,0 & 97,9 \\
\hline Total UE & 67,4 & 23,1 & 7,3 & 97,9 & 2,1 & 100,0 & 90,2 \\
\hline \multicolumn{8}{|c|}{$\begin{array}{l}\text { *Solo se incluyen las empresas que se han podido cruzar con el directorio de empresas de cada país, por lo que se excluyen los unknown en terminología } \\
\text { de Eurostat. }\end{array}$} \\
\hline
\end{tabular}


CUADRO 15B

EXPORTACIONES (COMERCIO TOTAL) DE LAS EMPRESAS EXPORTADORAS POR ESTRATO DE ASALARIADOS EN 2017 (10 PRINCIPALES PAÍSES EXPORTADORES DE LA UE)

\begin{tabular}{|c|c|c|c|c|c|c|c|}
\hline \multirow[b]{2}{*}{ País/estrato } & \multicolumn{6}{|c|}{ Exportaciones de empresas exportadoras del directorio de empresas* (millones de euros) } & \multirow[b]{2}{*}{$\begin{array}{c}\text { Total } \\
\text { exportadores } \\
\text { (operadores) }\end{array}$} \\
\hline & $\begin{array}{c}0 \text { a } 9 \\
\text { asalariados } \\
\text { micro }\end{array}$ & $\begin{array}{c}10 \text { a } 49 \\
\text { asalariados } \\
\text { pequeña }\end{array}$ & $\begin{array}{c}50 \text { a } 249 \\
\text { asalariados } \\
\text { mediana }\end{array}$ & $\begin{array}{c}\text { Pyme } \\
\text { (0 a } 249 \\
\text { asalariados) }\end{array}$ & $\begin{array}{c}>=250 \\
\text { asalariados } \\
\text { grande }\end{array}$ & $\begin{array}{c}\text { Total } \\
\text { empresas } \\
\text { directorio }\end{array}$ & \\
\hline Alemania & 50.469 & 65.201 & 140.626 & 256.295 & 856.727 & 1.113 .023 & 1.281 .946 \\
\hline Países Bajos & 40.764 & 63.646 & 135.657 & 240.067 & 130.286 & 370.354 & 577.088 \\
\hline Francia & 22.436 & 24.500 & 45.458 & 92.394 & 317.682 & 410.076 & 473.721 \\
\hline Italia & 24.152 & 75.067 & 125.077 & 224.296 & 200.827 & 425.123 & 449.132 \\
\hline Reino Unido & 59.073 & 33.443 & 56.453 & 148.968 & 212.878 & 361.846 & 390.124 \\
\hline Bélgica & 23.408 & 38.131 & 69.455 & 130.994 & 116.050 & 247.043 & 381.710 \\
\hline España & 32.681 & 36.634 & 61.389 & 130.705 & 125.248 & 255.952 & 283.095 \\
\hline Polonia & 9.609 & 13.833 & 29.904 & 53.346 & 107.550 & 160.896 & 207.334 \\
\hline Rep. Checa & 4.132 & 8.260 & 21.225 & 33.617 & 73.690 & 107.307 & 161.232 \\
\hline Austria & 22.350 & 17.101 & 30.631 & 70.082 & 74.944 & 145.027 & 148.756 \\
\hline Total UE & 389.906 & 453.986 & 885.268 & 1.729 .160 & 2.678 .041 & 4.407.201 & 5.228 .732 \\
\hline \multirow[b]{2}{*}{ País/estrato } & \multicolumn{6}{|c|}{ Porcentaje sobre el total de empresas exportadoras del directorio de empresas* } & \multirow{2}{*}{$\begin{array}{c}\% \\
\text { exportadores } \\
\text { directorio } \\
\text { s. total } \\
\text { exportadores }\end{array}$} \\
\hline & $\begin{array}{c}0 \text { a } 9 \\
\text { asalariados } \\
\text { micro }\end{array}$ & $\begin{array}{c}10 \text { a } 49 \\
\text { asalariados } \\
\text { pequeña }\end{array}$ & $\begin{array}{c}50 \text { a } 249 \\
\text { asalariados } \\
\text { mediana }\end{array}$ & $\begin{array}{c}\text { Pyme } \\
\text { (0 a } 249 \\
\text { asalariados) }\end{array}$ & $\begin{array}{l}\quad>=250 \\
\text { asalariados } \\
\text { grande }\end{array}$ & $\begin{array}{c}\text { Total } \\
\text { empresas } \\
\text { directorio }\end{array}$ & \\
\hline Alemania & 4,5 & 5,9 & 12,6 & 23,0 & 77,0 & 100,0 & 86,8 \\
\hline Países Bajos & 11,0 & 17,2 & 36,6 & 64,8 & 35,2 & 100,0 & 64,2 \\
\hline Francia & 5,5 & 6,0 & 11,1 & 22,5 & 77,5 & 100,0 & 86,6 \\
\hline Italia & 5,7 & 17,7 & 29,4 & 52,8 & 47,2 & 100,0 & 94,7 \\
\hline Reino Unido & 16,3 & 9,2 & 15,6 & 41,2 & 58,8 & 100,0 & 92,8 \\
\hline Bélgica & 9,5 & 15,4 & 28,1 & 53,0 & 47,0 & 100,0 & 64,7 \\
\hline España & 12,8 & 14,3 & 24,0 & 51,1 & 48,9 & 100,0 & 90,4 \\
\hline Polonia & 6,0 & 8,6 & 18,6 & 33,2 & 66,8 & 100,0 & 77,6 \\
\hline Rep. Checa & 3,9 & 7,7 & 19,8 & 31,3 & 68,7 & 100,0 & 66,6 \\
\hline Austria & 15,4 & 11,8 & 21,1 & 48,3 & 51,7 & 100,0 & 97,5 \\
\hline Total UE & 8,8 & 10,3 & 20,1 & 39,2 & 60,8 & 100,0 & 84,3 \\
\hline \multirow[b]{2}{*}{ País/estrato } & \multicolumn{6}{|c|}{ Exportación media de las exportadoras del directorio de empresas* (millones de euros) } & \multirow[b]{2}{*}{$\begin{array}{c}\text { Total } \\
\text { exportadores } \\
\text { (operadores) }\end{array}$} \\
\hline & $\begin{array}{c}0 \text { a } 9 \\
\text { asalariados } \\
\text { micro }\end{array}$ & $\begin{array}{c}10 \text { a } 49 \\
\text { asalariados } \\
\text { pequeña }\end{array}$ & $\begin{array}{c}50 \text { a } 249 \\
\text { asalariados } \\
\text { mediana }\end{array}$ & $\begin{array}{c}\text { Pyme } \\
\text { (0 a } 249 \\
\text { asalariados) }\end{array}$ & $\begin{array}{c}>=250 \\
\text { asalariados } \\
\text { grande }\end{array}$ & $\begin{array}{c}\text { Total } \\
\text { empresas } \\
\text { directorio }\end{array}$ & \\
\hline Alemania & 0,29 & 1,12 & 6,33 & 1,01 & 123,16 & 4,28 & 4,32 \\
\hline Países Bajos & 0,48 & 3,93 & 26,73 & 2,27 & 102,43 & 3,47 & 4,99 \\
\hline Francia & 0,34 & 1,20 & 6,00 & 0,99 & 109,17 & 4,24 & 4,42 \\
\hline Italia & 0,19 & 1,36 & 11,54 & 1,15 & 99,86 & 2,15 & 2,02 \\
\hline Reino Unido & 0,85 & 1,10 & 5,44 & 1,35 & 60,51 & 3,17 & 3,30 \\
\hline Bélgica & 0,77 & 3,36 & 24,80 & 2,93 & 146,53 & 5,44 & 4,68 \\
\hline España & 0,31 & 1,12 & 6,73 & 0,89 & 49,80 & 1,72 & 1,71 \\
\hline Polonia & 0,11 & 0,54 & 3,34 & 0,43 & 42,26 & 1,27 & 1,63 \\
\hline Rep. Checa & 0,64 & 1,44 & 5,77 & 2,13 & 60,50 & 6,30 & 8,77 \\
\hline Austria & 0,77 & 1,73 & 10,51 & 1,67 & 78,15 & 3,38 & 3,40 \\
\hline Total UE & 0,39 & 1,31 & 8,09 & 1,18 & 84,87 & 2,95 & 3,15 \\
\hline
\end{tabular}


En el análisis de la exportación media por empresa exportadora del directorio, España se sitúa por debajo de la UE en todos los tramos. Así, la exportación media por empresa alcanzó los 1,72 millones, cifra un 41,7\% inferior a la del conjunto de la UE. De los diez principales países exportadores, tan solo la cifra de Polonia se situó por debajo (1,27 millones). Las mayores diferencias se produjeron en las grandes empresas exportadoras del directorio, donde en España exportaron en media 49,80 millones de euros, lejos de los 84,87 millones del conjunto de la UE y todavía más de los 123,16 millones de Alemania, 109,17 millones de Francia o los 99,86 millones de Italia.

Por lo que se refiere a la propiedad nacional o extranjera de la empresa, en España, en 2017, había 7.086 empresas exportadoras DIRCE controladas por propietarios extranjeros, que, a pesar de representar únicamente el $4,8 \%$ de las empresas exportadoras del directorio, fueron responsables del $38,9 \%$ del valor de las exportaciones. El resto de las exportaciones (61,1\% del total) fue realizado por empresas controladas por propietarios nacionales, repartiendo el valor entre el $33,7 \%$ del total para las que no tienen filiales en el exterior (138.272 empresas) y $27,4 \%$ para las que sí tienen (3.602 empresas). Es de destacar que estas últimas registraron unas exportaciones medias de 19,5 millones de euros, cifra incluso superior a la de la media de empresas controladas por propietarios extranjeros (14,0 millones).

Eurostat también presenta estos mismos datos desglosados por países, aunque únicamente para trece Estados miembros (Cuadro 17). Entre estos, el porcentaje de las exportaciones realizadas por empresas controladas por propietarios nacionales en España $(61,1 \%)$ solo es superado por el correspondiente a Alemania $(68,3 \%)$ y a Dinamarca $(68,0 \%)$. En el extremo opuesto se situarían Bélgica, República Checa y Reino Unido, donde la mayor parte de sus exportaciones fueron realizadas por las empresas controladas por propietarios extranjeros, aglutinando, respectivamente, el $78,5 \%$, $76,1 \%$ y $62,5 \%$ de sus exportaciones. Las empresas que o bien están bajo control extranjero o bien, estando bajo control nacional, tienen filiales en el extranjero fueron responsables en España de prácticamente dos terceras partes del comercio en 2017 (66,3\%), lo que mostraría la elevada integración de España en las cadenas globales de valor.

La propensión exportadora general de las empresas DIRCE en España, definida como la proporción del número de empresas del directorio que exportan respecto al total, fue del $4,5 \%$ en 2017. Si se analiza esa misma ratio para cada tamaño de empresa, se observa, $\square$

CUADRO 16

ESPAÑA: NÚMERO DE EMPRESAS EXPORTADORAS POR TIPO DE PROPIEDAD EN 2017

\begin{tabular}{|c|c|c|c|c|c|c|}
\hline \multirow{2}{*}{ Variable } & \multicolumn{3}{|c|}{$\begin{array}{l}\text { Empresas controladas por propietarios } \\
\text { nacionales }\end{array}$} & \multirow{2}{*}{$\begin{array}{c}\text { Empresas } \\
\text { controladas por } \\
\text { propietarios } \\
\text { extranjeros }\end{array}$} & \multirow{2}{*}{$\begin{array}{c}\text { Total } \\
\text { empresas } \\
\text { (directorio } \\
\text { empresas) }\end{array}$} & \multirow{2}{*}{$\begin{array}{c}\text { Total } \\
\text { exportadores } \\
\text { (operadores) }\end{array}$} \\
\hline & $\begin{array}{l}\text { Con filiales en } \\
\text { el extranjero }\end{array}$ & $\begin{array}{l}\text { Sin filiales en } \\
\text { el extranjero }\end{array}$ & $\begin{array}{c}\text { Total } \\
\text { nacionales }\end{array}$ & & & \\
\hline Número & 3.602 & 138.372 & 141.974 & 7.086 & 149.060 & 165.623 \\
\hline$\%$ s. directorio & 2,4 & 92,8 & 95,2 & 4,8 & 100,0 & - \\
\hline Millones de euros & 70.142 & 86.301 & 156.443 & 99.510 & 255.952 & 283.095 \\
\hline$\%$ s. directorio & 27,4 & 33,7 & 61,1 & 38,9 & 100,0 & - \\
\hline Millones de euros / empresa & 19,5 & 0,6 & 1,1 & 14,0 & 1,7 & 1,7 \\
\hline
\end{tabular}

Fuente: Eurostat. 
CUADRO 17

UE: EMPRESAS EXPORTADORAS POR TIPO DE PROPIEDAD EN 2017, EN PORCENTAJE SOBRE EL VALOR EXPORTADO (PAÍSES CON DATOS)

\begin{tabular}{|c|c|c|c|c|c|c|}
\hline \multirow{2}{*}{ País } & \multicolumn{3}{|c|}{$\begin{array}{c}\text { Empresas controladas por propietarios nacionales } \\
\text { (\%) }\end{array}$} & \multirow{2}{*}{$\begin{array}{c}\text { Empresas } \\
\text { controladas por } \\
\text { propietarios } \\
\text { extranjeros (\%) }\end{array}$} & \multirow{2}{*}{$\begin{array}{c}\text { Total empresas } \\
\text { del directorio } \\
\text { (Millones de } \\
\text { euros) }\end{array}$} & \multirow{2}{*}{$\begin{array}{c}\text { Total exportadores } \\
\text { (operadores) } \\
\text { (Millones de euros) }\end{array}$} \\
\hline & $\begin{array}{l}\text { Con filiales en el } \\
\text { extranjero }\end{array}$ & $\begin{array}{l}\text { Sin filiales en el } \\
\text { extranjero }\end{array}$ & $\begin{array}{l}\text { Total } \\
\text { nacionales }\end{array}$ & & & \\
\hline Alemania & - & - & 68,3 & 31,7 & 1.032 .530 & 1.281 .946 \\
\hline Reino Unido & 37,4 & 0,1 & 37,5 & 62,5 & 294.325 & 390.124 \\
\hline Bélgica & 9,6 & 11,9 & 21,5 & 78,5 & 188.012 & 381.710 \\
\hline España & 27,4 & 33,7 & 61,1 & 38,9 & 255.952 & 283.095 \\
\hline Polonia & 7,4 & 35,9 & 43,3 & 56,7 & 160.938 & 207.334 \\
\hline República Checa & - & - & 23,9 & 76,1 & 109.161 & 161.232 \\
\hline Dinamarca & 39,4 & 28,5 & 68,0 & 32,0 & 87.825 & 90.633 \\
\hline Rumanía & 1,1 & 28,5 & 29,7 & 70,3 & 61.399 & 62.625 \\
\hline Finlandia & 49,7 & 8,4 & 58,1 & 41,9 & 54.325 & 60.239 \\
\hline Portugal & 17,5 & 40,6 & 58,1 & 41,9 & 53.520 & 55.018 \\
\hline Eslovenia & 30,1 & 24,1 & 54,2 & 45,8 & 25.173 & 34.007 \\
\hline Lituania & 6,9 & 45,2 & 52,1 & 47,9 & 20.433 & 26.411 \\
\hline Chipre & 17,5 & 30,2 & 47,7 & 52,3 & 2.872 & 2.904 \\
\hline
\end{tabular}

como parece razonable, que la probabilidad de que una empresa exporte aumenta con el tamaño. En 2017, tan solo 3,3\% de las microempresas exportaron, frente al $59,7 \%$ de las grandes empresas. La propensión exportadora de las pymes también era del $4,5 \%$.
Atendiendo a la actividad principal, las empresas de la industria manufacturera (sección $C$ de la CNAE 2009) registran una propensión exportadora del $21,2 \%$, frente al $4,5 \%$ del conjunto de la economía. Si se analizan las empresas de la industria manufacturera de más de $D$

CUADRO 18

ESPAÑA: NÚMERO DE EMPRESAS EXPORTADORAS DEL DIRECTORIO POR ESTRATO DE ASALARIADOS (COMERCIO TOTAL) EN 2017

\begin{tabular}{|c|c|c|c|c|c|}
\hline \multirow[b]{2}{*}{ Estrato de asalariados } & \multirow{2}{*}{$\begin{array}{c}\text { Empresas } \\
\text { exportadoras } \\
\text { del directorio }\end{array}$} & \multirow{2}{*}{$\begin{array}{l}\text { Empresas } \\
\text { DIRCE }\end{array}$} & \multicolumn{2}{|c|}{ Porcentaje sobre total } & \multirow{2}{*}{$\begin{array}{c}\text { Porcentaje } \\
\text { exportadoras sobre } \\
\text { total DIRCE }\end{array}$} \\
\hline & & & $\begin{array}{c}\text { Empresas } \\
\text { exportadoras DIRCE }\end{array}$ & $\begin{array}{l}\text { Total empresas } \\
\text { DIRCE }\end{array}$ & \\
\hline 0-9 microempresa & 104.624 & 3.136 .869 & 70,2 & 95,6 & 3,3 \\
\hline 10-49 pequeña & 32.802 & 120.711 & 22,0 & 3,7 & 27,2 \\
\hline 50-249 mediana & 9.119 & 20.550 & 6,1 & 0,6 & 44,4 \\
\hline $0-249$ pyme & 146.545 & 3.278 .130 & 98,3 & 99,9 & 4,5 \\
\hline$>=250$ gran empresa & 2.515 & 4.216 & 1,7 & 0,1 & 59,7 \\
\hline Total & 149.060 & 3.282 .346 & 100,0 & 100,0 & 4,5 \\
\hline \multicolumn{6}{|c|}{ Sector industrial } \\
\hline Industria manufacturera (CNAE C) & 36.889 & 174.090 & 24,7 & 5,3 & 21,2 \\
\hline Total industria (CNAE B, C, D y E) & 37.837 & 198.805 & 25,4 & 6,1 & 19,0 \\
\hline \multicolumn{6}{|c|}{ Sector industrial (más de 10 asalariados) } \\
\hline Industria manufacturera (CNAE C) & 18.716 & 28.547 & 12,6 & 0,9 & 65,6 \\
\hline Total industria (CNAE B, C, D y E) & 19.206 & 30.464 & 12,9 & 0,9 & 63,0 \\
\hline
\end{tabular}


Subdirección General de Estudios y Evaluación de Instrumentos de Política Comercial

CUADRO 19

EMPRESAS EXPORTADORAS SEGÚN TIPOLOGÍA EN 2017, EN PORCENTAJE SOBRE DIRECTORIO (10 PRINCIPALES EXPORTADORES DE LA UE)

\begin{tabular}{|l|c|c|c|c|c|c|}
\hline \multirow{2}{*}{ País } & \multicolumn{2}{|c|}{ Núm. empresas directorio } & Núm. empresas (\% s. directorio) & \multicolumn{2}{c|}{ Valor exportado (\% s. directorio) } \\
\cline { 2 - 7 } & $\begin{array}{c}\text { Solo } \\
\text { exportadores }\end{array}$ & $\begin{array}{c}\text { Exportadores- } \\
\text { importadores }\end{array}$ & $\begin{array}{c}\text { Solo } \\
\text { exportadores }\end{array}$ & $\begin{array}{c}\text { Exportadores- } \\
\text { importadores }\end{array}$ & $\begin{array}{c}\text { Solo } \\
\text { exportadores }\end{array}$ & $\begin{array}{c}\text { Exportadores- } \\
\text { importadores }\end{array}$ \\
\hline Alemania & 69.642 & 190.386 & 26,8 & 73,2 & 1,0 & 99,0 \\
Países Bajos & 30.287 & 76.522 & 28,4 & 71,6 & 1,0 & 99,0 \\
Francia & 53.761 & 47.957 & 52,9 & 47,1 & 3,1 & 96,9 \\
Italia & 86.172 & 111.511 & 43,6 & 56,4 & 2,8 & 97,2 \\
Reino Unido & 40.900 & 73.222 & 35,8 & 64,2 & 3,4 & 96,6 \\
Bélgica & 12.115 & 69.357 & 14,9 & 85,1 & 1,3 & 98,7 \\
España & 49.165 & 99.895 & 33,0 & 67,0 & 3,5 & 96,5 \\
Polonia & 54.819 & 72.341 & 43,1 & 56,9 & 3,3 & 96,7 \\
Rep. Checa & 6.461 & 11.924 & 35,1 & 64,9 & 4,5 & 95,5 \\
Austria & 5.218 & 37.646 & 12,2 & 87,8 & 1,5 & 98,5 \\
\hline Fuente: Eurostat. & \multicolumn{7}{|r|}{} \\
\hline
\end{tabular}

diez asalariados la propensión exportadora aumenta hasta el 65,6\%. Los datos son muy similares si se amplía a la industria en su conjunto (secciones B, C, D y E de la CNAE 2009), con una propensión exportadora del $19,0 \%$ y del $63,0 \%$ para las de más de diez asalariados.

Otro factor que parece determinante a la hora de exportar es si la empresa exportadora es a su vez importadora. En el Cuadro 19 se muestran las estadísticas de los diez principales países exportadores de la UE. Así, en 2017 la práctica totalidad de las exportaciones españolas en 2017 (96,5\%) fueron realizadas por las empresas que realizaron al mismo tiempo actividades de exportación e importación (99.895 empresas, $67,0 \%$ del total de las empresas exportadoras), quedando el resto para 49.195 empresas exportadoras DIRCE que únicamente exportaron.

En el resto de principales países exportadores de la UE las empresas que exportan e importan al mismo tiempo también aglutinaron más del 95\% de las exportaciones, si bien los pesos de estas empresas sobre el total de exportadores difieren. Estos datos son coherentes con la idea de que importar puede facilitar la actividad exportadora. Las razones de que así sea pueden ser múltiples y variadas, como la mejora de la competitividad al poder beneficiarse de inputs de mayor calidad o a mejor precio; o el mayor conocimiento de las redes y prácticas comerciales, así como las preferencias de los consumidores de los países desde los que se importa, en el proceso conocido en la literatura académica como learning by importing.

\section{Conclusiones}

A partir de los datos analizados de Aduanas (comercio declarado de empresas DIRCE) y Eurostat (comercio total de empresas del directorio) se puede extraer una serie de rasgos característicos de las empresas exportadoras españolas, cuyo conocimiento puede resultar de utilidad, tanto para comprender la dinámica de las exportaciones como para conocer mejor a la base exportadora y adaptar a sus características el diseño e implementación de las políticas de apoyo a la internacionalización de las empresas.

En primer lugar, y con respecto al tamaño, se observa que la inmensa mayoría de las $\triangleright$ 
empresas exportadoras DIRCE de comercio declarado son pymes $(97,5 \%)$, si bien sus exportaciones apenas representan la mitad del valor total $(50,1 \%)$, dejando el resto para un número reducido de grandes empresas. Precisamente, en el análisis de la concentración se observa que más de dos tercios de las exportaciones lo realizan las mil primeras empresas exportadoras $(67,5 \%)$.

Asimismo, conviene resaltar que la inmensa mayoría de las exportaciones, el 96,4\% del comercio declarado de empresas DIRCE en 2017, lo realizan empresas que exportan de manera regular. Aproximadamente la mitad de las empresas $(49,0 \%)$ son exportadoras regulares, proporción que aumenta hasta alrededor del $80 \%$ en las medianas y grandes empresas.

La mayor parte de las empresas exportadoras tienen como actividad principal o bien el comercio $(43,8 \%)$ o bien la industria manufacturera $(27,4 \%)$, siendo estas empresas las responsables de más del $95 \%$ de las exportaciones. En concreto, casi dos tercios para la industria manufacturera y más de un $30 \%$ para el comercio. Las empresas en estas actividades presentan una mayor regularidad en sus exportaciones. Así, el 67,6\% de las empresas de la industria manufacturera exportan de forma regular, y dentro del comercio destacan por su regularidad las del comercio al por mayor, con el $58,1 \%$.

Por destinos geográficos, aproximadamente dos terceras partes del comercio declarado se dirige a la UE (66,8\% en 2017). La mitad de las empresas exportadoras DIRCE de comercio declarado exportan a un único destino, aunque con una incidencia mínima en las exportaciones $(2,3 \%$ de total). Por el contrario, el grueso de las exportaciones $(68,5 \%$ del total) fueron realizadas por las empresas que exportaron a veinte o más destinos.
La propensión a exportar de las empresas españolas aumenta muy significativamente con el tamaño y es notablemente superior en la industria. Así, si la propensión a exportar para el conjunto de las empresas es del $4,5 \%$, aumenta hasta el $21,2 \%$ en la industria manufacturera y hasta el $65,6 \%$ de las empresas manufactureras de más de diez asalariados.

En cuanto al control de las empresas, las controladas por propietarios extranjeros y las de propiedad nacional con filiales en el exterior suponen alrededor de dos tercios de las exportaciones. Así, las empresas controladas por propietarios extranjeros contribuyen con cerca del $40 \%$ al valor exportado. Dentro de las exportaciones realizadas por empresas controladas por propietarios nacionales (más del $60 \%$ del valor total) destacan, por su peso en las exportaciones, las empresas que tienen filiales en el exterior (que contribuyen con un $27,4 \%$ al total).

Otro factor que parece determinante a la hora de exportar es si la empresa es, a su vez, importadora. Así, la práctica totalidad de las exportaciones $(96,5 \%)$ son realizadas por las empresas que exportan e importan al mismo tiempo.

La relevancia de la propiedad extranjera, la propiedad de filiales en el exterior y las importaciones entre las empresas exportadoras constituyen, posiblemente, un indicador de su inserción en cadenas globales de valor.

En cuanto a la comparativa con otras economías de la UE, por tamaño, en España sobresalen, tanto en número como en valor de sus exportaciones, las microempresas, y en el extremo contrario, por el menor peso en número y en valor de las exportaciones, las grandes empresas. Las exportaciones medias de las empresas exportadoras españolas son inferiores a la media de la UE para todos los tamaños de empresa. 
Subdirección General de Estudios y Evaluación de Instrumentos de Política Comercial

\section{Bibliografía}

Departamento de Aduanas (varios años). Comercio exterior por características de la empresa. Recuperado de https://www.agenciatributaria. es/AEAT.internet/datosabiertos/catalogo/hacienda/datos_estadisticos_Comercio_Exterior.shtml

Eurostat (2019). Database. Recuperado de http:// ec.europa.eu/eurostat/data/database

Instituto Nacional de Estadística (2018). Directorio Central de Empresas. Recuperado de https:// www.ine.es/dyngs/INEbase/es/operacion. htm?c=Estadistica_C\&cid $=1254736160707 \&$ menu $=$ ultiDatos\&idp $=1254735576550$

Secretaría de Estado de Comercio (mensuales). Informe Mensual de Comercio Exterior. Recuperado

de http://www.comercio.gob.es/es-ES/comercio-exterior/estadisticas-informes/Paginas/Informes-de-Comercio-Exterior.aspx

Secretaría de Estado de Comercio (2017). Estrategia de Internacionalización de la Economía Española 2017-2027. Recuperado de http:// www.mineco.gob.es/stfls/mineco/comercio/ pdf/170913_Estrategia_Internacionalizacion_2017.pdf

Secretaría de Estado de Comercio (2019). Plan de Acción para la Internacionalización de la Economía Española 2019-2020. Recuperado de http://www.comercio.gob.es/es-ES/PDF/portada/Plan\%20Internacionalizaci\%C3\%B3n\%20 19-20.pdf 


\section{ANEXO \\ ACLARACIONES METODOLÓGICAS}

La población objeto de estudio de los datos de Aduanas en su publicación de Comercio exterior por características de la empresa está constituida por las empresas que, habiendo declarado operaciones de comercio exterior, bien con países de la UE, bien con terceros países, figuren también en el año de referencia en el Directorio Central de Empresas (DIRCE), elaborado por el INE. Se trata, por tanto, de un ámbito más restringido que el de los operadores de comercio exterior.

Con respecto a los datos deben realizarse las siguientes distinciones:

- Entre operadores y empresas del directorio de empresas.

- Entre comercio declarado y comercio total.

El término operador exportador es más amplio que el de empresa exportadora, ya que se trata de cualquier unidad que haya realizado al menos una operación de exportación, pero no se trata necesariamente de una empresa en sentido amplio. Los operadores de comercio declarado son aquellas unidades que, siguiendo la legislación vigente, han declarado al menos una operación de comercio exterior. La legislación impone obligaciones de declaración distintas según se trate de operaciones extracomunitarias (sistema Extrastat) o de operaciones intracomunitarias (sistema Intrastat).

En las operaciones con países terceros (Extrastat), está obligada a presentar la declaración aduanera toda persona física o jurídica que intervenga en actos a los que les sea de aplicación la legislación aduanera. Ello significa que toda operación de comercio exterior queda debida y puntualmente registrada en las correspondientes declaraciones aduaneras (a través del DUA, Documento Único Administrativo). Por tanto, en el sistema Extrastat, el comercio declarado se corresponde con el comercio total, salvo excepciones muy residuales derivadas de registros faltantes, retrasados o incompletos. Precisamente, en las operaciones con terceros países sí puede haber un número significativo de obligados a realizar la declaración aduanera que no tengan la consideración de empresa, por ejemplo, por envíos entre particulares que superen cierto valor.

Por su parte, en las operaciones intracomunitarias (sistema Intrastat), el obligado a presentar la declaración estadística Intrastat es la persona física o jurídica sujeta al impuesto sobre el valor añadido que haya formalizado el contrato cuyo efecto sea la expedición o introducción de las mercancías y que haya superado el correspondiente umbral de exención (entre 2008 y 2014 fue de 250.000 euros por flujo, y desde 2015 aumentó hasta los 400.000 euros). La existencia de este umbral de exención permite que aquellos operadores que realicen operaciones de ámbito intracomunitario por debajo del mismo no estén obligados a presentar las declaraciones Intrastat. De ahí que haya una parte de comercio que no se declara, pero que sí ha tenido lugar, y su estimación conforma la principal diferencia entre el comercio declarado y el comercio total. Existe un segundo elemento, aunque de menor cuantía, que corresponde a las operaciones intracomunitarias de operadores que, habiendo superado el umbral y, por tanto, dado lugar a la obligación de presentar las declaraciones Intrastat, no la hayan presentado. Para poder ofrecer estos componentes, Aduanas ha implantado un método de estimación robusto basado en las declaraciones recapitulativas de las operaciones intracomunitarias del IVA (modelo 349).

Precisamente, la elevación del umbral de exención hasta los 400.000 euros en 2015 hace que las comparaciones de este año con los anteriores deban realizarse con mucha cautela, ya que a partir de 2015 dejan de figurar como comercio declarado las operaciones intracomunitarias de aquellos operadores con expediciones entre los 250.000 y 399.999 euros para el caso de las exportaciones.

Eurostat, a diferencia de Aduanas en la publicación de los datos para España, presenta los datos teniendo en cuenta el comercio total, es decir, incluyendo la estimación de comercio intracomunitario bajo umbral y la $D$ 
estimación de no presentación. Por ello, los datos de Eurostat para España, tanto en valor como sobre todo en número de exportadores o de empresas exportadoras, serán superiores a los que ofrece Aduanas.

Los datos de los operadores, ya sean de comercio declarado o de comercio total, se cruzan con el del directorio de empresas generalmente a través del número de identificación fiscal. Aduanas cruza para España los datos de los operadores de comercio declarado con el DIRCE, mientras que Eurostat cruzará para cada país los datos de los operadores de comercio total con los directorios de empresas respectivos.

EI DIRCE es un registro de las empresas españolas que cubre todas las actividades económicas a excepción de la producción agraria y pesquera, los servicios administrativos de la Administración central, autonómica y local (incluida la Seguridad Social), las actividades de las comunidades de propietarios y el servicio doméstico. Por ello no cruzarán con el DIRCE ni las empresas extranjeras que realicen exportaciones desde España ni las empresas de las actividades económicas excluidas. En ambos casos, se trata de un número reducido de empresas, si bien las empresas extranjeras pueden realizar exportaciones por importes significativos. 